\title{
Psikolojik Sözleşme İhlali İle Örgütsel Bağlılık Arasında Örgütsel Güvenin Aracılık Rolü ${ }^{1}$
}

\author{
Murat GÜNEY ${ }^{2}$ ve Mehmet TURAN ${ }^{3}$
}

\section{$\ddot{\mathrm{O} z}$}

Psikolojik sözleşmeler günümüz yazılı sözleşmelerinin fiziki imkansızlık nedeniyle kapsayamadığı çalışma ilişkisinin tüm açı ya da örtük taahhüt ve yükümlülükleri kapsamaktadır. Bu taahhüt ve yükümlülüklerin zaman içinde karşılanmaması ya da imkansızlık nedeniyle karşılanamaması durumunda çalışanlarda psikolojik sözleşme ihlali algısı oluşmaktadır. Psikolojik sözleşme ihlali algısının örgütsel bağlllık üzerindeki etkisi daha önce gerçekleştirilen çalışmalarda incelenmiştir, bu çalışmada ise örgütsel güvenin bu ilişkiyi nasıl etkilediği ortaya konulmaya çalışılacaktır. Bu çalışmanın temel amacı çalışanlarının psikolojik sözleşme ihlali algıllarının örgüte olan bağlılıklarını ve örgüte olan güvenlerini nasıl etkilediğini tespit etmek ve bu süreç içinde güven kaybının bağlıllı̆̆a olan dolaylı etkisini ortaya koymaktır. Çalışmada sunulan hipotezlerin test edilmesi için sağlık sektöründe çalışan 261 çalışandan oluşan bir örneklemden alınan veriler kullanılmıştır. Araştırma modeli katılımcıların psikolojik sözleşme ihlali algısını, örgütsel güven ve örgütsel bağlılık seviyelerini değerlendirmeleri amacıyla, yazında kullanılan ölçeklerden yararlanılarak hazırlanan anket kullanılarak test edilmiştir. Sonuçlar psikolojik sözleşme ihlali algısının örgütsel bağlllı̆̆a olan etkisinde örgütsel güvenin kısmi aracılık rolünün varlığını ortaya koymuştur. Çalışmada araştırma sonuçlarının gelecekteki araştırmalar için pratik sonuçları tartışılmıştır. Ayrıca çalışma, psikolojik sözleşme ihlali, örgütsel güven ve örgütsel bağlliık kuramlarını genişletmektedir.

Anahtar Kelimeler: Psikolojik sözleşme, Psikolojik sözleşme ihlali, Örgütsel bağlllık, Örgütsel güven

\section{The Mediating Role of Organizational Trust between Psychological Contract Violation} and Organizational Commitment

\section{Abstract}

Psychological contracts encompass all explicit or implicit commitments and obligations of the working relationship, which today's written contracts cannot cover due to physical impossibility. The effect of the perception of violation of psychological contract on organizational commitment has been examined in previous studies, and this study will try to determine how organizational trust affects this relationship. The major aim of this study is to determine how psychological contract perceptions of private hospital employees affect their commitment and trust in the organization, and to reveal the indirect effect of loss of trust on loyalty in this process. In order to test the hypotheses presented in the study, data from a sample of 261 employees were used. The research model was tested using validated questionnaires to assess participants' perception of psychological contract violations, organizational trust and organizational commitment levels. The results showed that there is a partial mediating role of organizational trust in the effect of perception of psychological contract violation on organizational commitment. In this study, the practical results of the research results for future researches are also discussed. In addition, the study extends the theories of psychological contract violation, organizational trust and organizational commitment.

Key Words: Psychological contract violation, Organizational trust, Organizational commitment

\section{Atıf İçin / Please Cite As:}

Güney, M. ve Turan, M. (2021). Psikolojik sözleşme ihlali ile örgütsel bağlllik arasında örgütsel güvenin aracıllk rolü. Manas Sosyal Araștırmalar Dergisi, 10(1), 356-374.

Geliş Tarihi / Received Date: 07.02.2020

Kabul Tarihi / Accepted Date: 24.09.2020

\footnotetext{
1 Yüksek Lisans Tezinden üretilmiştir.

2 Doktora Öğrencisi - Çukurova Üniversitesi, Sosyal Bilimler Enstitüsü, mrtgny@gmail.com

iD ORCID: 0000-0003-3894-1204

3 Prof. Dr. - Çukurova Üniversitesi, İktisadi ve İdari Bilimler Fakültesi, mturan@cu.edu.tr

iD ORCID: 0000-0003-1297-0461
} 


\section{Giriş}

İşveren ve çalışan arasında akdedilen yazılı sözleşmeler iş ilişkisi içerisinde yer alan tüm beklenti ve yükümlülükleri kapsamada yetersiz kalmaktadır. İş ilişkisinin karmaşık beklenti/yükümlülük süreçlerindeki yazılı sözleşmeler içinde yer alamayan tüm hükümler psikolojik sözleşme dâhilindedir. Psikolojik sözleşmeler iş akdi ile başlayıp iş akdi sonlanana kadar çalışan tutum ve davranışlarını şekillendirmektedir.

Psikolojik sözleşme son yillarda çalş̧an ve işveren beklentilerinin daha iyi anlaşılması açısından yaygin olarak araştırılan bir kavram olarak ortaya çıkmaktadır (Dağl1, 2016). 1960’lı yıllardan günümüze değin gerçekleştirilen ve özellikle 1980'lerden sonra yapılan çalışmalarda genelde çalışan bakış açısı ile açıklanan psikolojik sözleşme kısaca işverenin çalışana karşı olan yükümlülüklerinin yerine getirilip getirilmediği konusundaki çalışan algisı olarak tanımlanabilir (Dağlı, 2016). Psikolojik sözleşmenin ihlal edildiği algısı oluşması durumunda çalışanların örgüte olan bağlılığında azalma ve buna bağlı olarak işten ayrılma niyeti geliştirme, performans azalması gibi olumsuz çalışan tutum ve davranışları ortaya çıkabilmektedir. Modern örgütsel yaşamda çalışanların iş ilişsisinden doğan işveren yükümlülüklerinin yerine getirilmediği yani psikolojik sözleşmesinin ihlal edildiği alg1sı çalışanın örgüte olan katkısını önemli ölçüde kısıtlayan bir olgudur. Örgütsel davranış yazını incelendiğinde psikolojik sözleşme ihlallerinin çalışan tutum ve davranışlarına olan direk etkileri ile örgütler üzerindeki dolaylı etkilerini ortaya koyan araştırmalara rastlanmaktadır. Psikolojik sözleşme ihlallerinin genel anlamda çalışan tutum ve davranışlarına olan negatif etkisi örgütlerin başarısını da olumsuz etkilemektedir. Ayrı ayrı birçok araştırmada psikolojik sözleşme ihlallerinin örgütsel bağlllık, örgütsel güven, örgütsel vatandaşlık davranışı ve işten ayrilma niyeti geliştirmeye etkileri incelenmiş olmasına rağmen çalışmamızın konusunu oluşturan psikolojik sözleşme ihlali algısının örgütsel bağllılı ile olan ilişkisinde örgütsel güvenin aracıllk rolünü inceleyen araştırmalara rastlanmamıştır.

Psikolojik sözleşme ihlallerinin en çok etkilediği çalışan davranışlarından biri olan örgütsel bağlllık, çalışanların örgüt hedeflerini benimsemeleri, örgütü büyük bir aile olarak görüp kendilerini de bu ailenin bir unsuru olarak hissetmeleridir. Çalışanlardaki örgütsel bağllık derecesi örgütsel hedef ve amaçlara ulaşmada örgüt yönetimi için oldukça önemlidir. Örgütsel bağllliğı zaylf olan çalısanlar örgütte geçirdikleri süreyi geçici olarak görmekte, bir sonraki iş ilişkilerine bir basamak olarak bakmaktadırlar. Bu anlamda herhangi bir kariyer beklentisi içinde değildirler ve örgüte olan katkıları da iş değiştirene kadar gerekli olan asgari seviyededir. Aksine örgütsel bağlllı̆̆1 yüksek olan çalsşanlar örgütte kalmayı seçtiklerinden ve yükselmeyi de hedeflediklerinden kendilerini aşmaya meyillidirler ve örgüte olan katkıları çok daha fazladır.

Öte yandan örgütsel güven ise genel anlamda çalışanın örgüt ve üyeleri hakkındaki güven duygusu, onlardan kendisine bir zarar gelmeyeceği hakkındaki kanaati olarak tanımlanabilir (Vineburgh, 2010). Günümüzde örgütlerde önemli bir iş yapış şekli olan takım çalışmalarının başarılı olabilmesi açısından çalışanların örgütsel güven düzeylerinin yüksek olması gerekmektedir. Bunun yanı sıra çalışanların örgüte ve yöneticilerine olan güveni örgüt içi iletişimi ve dolayısıyla örgütsel başarıyı da doğrudan etkilemektedir. S1klıkla güçlü bir şekilde ilişkilendirilmiş olmasına rağmen örgütsel güven kavramı ile örgütsel bağllık kavramı kavramsal olarak farklıdır. Örgütsel güven çalışanların yöneticilere ve şirket amaçlarına olan inancıyla ilişkili iken örgütsel bağllık şirket amaçlarına uygun bir kimlik edinme ile ilişkilidir (Gilbert ve Tang, 1998). Örgütsel güven seviyesi yüksek olan çalışanların örgütsel bağlılıkları da artmaktadır. Çalsşanların yöneticileri ve birbirleri ile olan iletişiminin kuvvetli olması duygu ve düşüncelerini rahatça ifade edebilmelerine olanak sağlamakta birbirlerine ve kuruma olan sadakatlerini güçlendirmektedir. Çalışanların ihtiyaç ve taleplerinin adil bir şekilde karşılanıyor olması, şirket ve yöneticiler tarafindan sürekli desteklenmeleri konusunda verilen güvence çalışanların örgütsel bağlılığını artırmaktadır (Paine, 2007). Kısaca özetlemek gerekirse psikolojik sözleşme ihlallerinin örgütsel bağlllğ̆a olan etkisinde örgütsel güvenin ayrıca bir katkısının olabileceği mümkün görülmektedir.

Bu nedenle bu çalışmada psikolojik sözleşme ihlali algısının örgütsel bağlllı̆̆a olan etkisinde örgütsel güvenin aracıllk rolü incelenmiştir. Psikolojik sözleşme ihlalinin hem örgütsel bağlllığa hem de örgütsel güvene olan direk etkilerinin yanı sıra örgütsel güvenin de örgütsel bağll1ığa olan etkileri araştırmanın konusunu oluşturmaktadır. 


\section{Kavramsal Çerçeve}

\section{Psikolojik Sözleşme ve İhlal Algısı}

Psikolojik sözleșmelerin konusunu İş Kanununda tanımlı yazılı iş sözleşmelerinde değinilmeyen boşluklar, belirsizlikler oluşturmaktadır (Erdoğan, 2015, s. 5). Günümüzde birçok araştırmacı tarafindan temel alınan Rousseau (1989, s. 123; 1995, s. 9) psikolojik sözleşmeyi "kişinin, kendisi ve örgütü arasındaki mübadele iliş̧kisinin koşullarına dair örgüt tarafindan biçimlendirilen kişisel inanç sistemi” biçiminde tanımlamaktadır. Tanımdan da anlaşılacağı üzere psikolojik sözleşme sosyal değişim (socialexchange) ilişkisi içine gömülü bir kavramdır. Gerçekten de psikolojik sözleşmenin iş ilişkisini anlamakla ilgili bir kavram olduğu konusunda yazında fikir birliği vardır, çünkü öncelikle sosyal değişimkuramı kavramına dayanan bir karşılıklı değişim anlaşmasını ifade eder. Basitçe söylemek gerekirse çalışan tarafından yapılan katkıların ve işveren tarafindan verilen teşviklerin alışverişinden oluşan bir iş ilişkisi vardır ve psikolojik sözleşmenin temel dayanağının karşılıklılık olduğu vurgulanmaktadır (Cassar, 2004).

Psikolojik sözleşmedeki açık / örtülü ayrımı sözleşme şartlarının sözleşme taraflarına iletilmesi ya da bunlara erişme şekli ile ilgilidir. Açık sözleşme şartları, yazılı ya da sözlü iletişimin yazılı olarak ya da örgütsel politikalar içeriği şeklinde iletilirler. Buna karşllı örtülü sözleşme şartları önceki çalışma tecrübelerinden kaynaklı kişisel çıkarımların altında yatar ve ayrıca diğer çalşsanların tutum ve davranışlarının gözlenmesi suretiyle edinilmektedir. Doğası gereği psikolojik sözleşmeler örtülüdür (Cassar, 2004).

Rousseau psikolojik sözleşmeleri işlemsel, ilişkisel, geçişsel ve dengeli olmak üzere dört türe ayırmıştır. Bununla birlikte ölçüm tekniklerindeki zorluklardan kaynaklı olarak kendi içinde işlemsel ve geçişsel sözleşme türleri ile ilişkisel ve dengeli sözleşme türleri arasındaki büyük benzerlik nedeniyle araştırmalar işlemsel ve ilişkisel sözleşme türleri ana başlikları altında yürütülmüştür. İlişkisel sözleşmeler iş ilişkisinde uzun bir süreyi kapsar ve örgütsel bağll11k ve örgütsel destek gibi ucu açık sosyal, duygusal yükümlülükleri içerir (Dağlı, 2016). İşlemsel sözleşmeler kısa vadeli, yüksek derecede parasal ve ekonomik odaklı psikolojik sözleşme türüdür (Rousseau, 1994).

Psikolojik sözleşme ihlali algısı işverenin kendi yükümlülüklerinden bir ya da birkaçını yerine getirmediğine yönelik çalışan görüşüdür (Dağl1, 2016). Rousseau’ya (1995) göre psikolojik sözleşme ihlali kişinin duygusal tepkilerinin takip ettiği sözleşme tutarsızlı̆̆ algısıdır. Buna karşılık Morrison ve Robinson’a (1997) göre ihlal algılanan tutarsızlığın sonucu olan duygusal tepkilerdir. Sözleşmeye uymama ve ihlal arasında fark vardır. Sözleşmeye uymama (breach) çalışanın örgütünün bir ya da daha fazla yükümlülügünü yerine getirmede başarısız olması algısıdır. İhlal ise sözleşmeye uymama durumunu izleyen duygusal durumdur (Morrison ve Robinson, 1997, s. 230).

\section{Örgütsel Güven}

Güven kavramının Oxford sözlüğünde yapılan tanımı; bir kimsenin iyi, dürüst ve içten olduğuna ya da karşı tarafi aldatmayı denemeyeceğine, zarar vermeyeceğine dair inanç, gerçek olduğuna dair bir kanıt olmasa da birinin sözlerine inanmak olarak yer almaktadır (Kalmaz, 2018). Güven kavramı yönetim ve örgütsel davranış yazınında önceleri göz ardı edilse de 1990’lı yıllardan sonra gereken önem verilmeye başlanmıştır. Örgüt içindeki kişiler kişisel ve örgütsel hedefleri gerçekleştirmek için birlikte çalışmalı ve dayanışma içinde olmalıdırlar (Mayer vd., 1995, s. 710). Bahsedilen dayanışma ortamı içinde güven, kişilerin davranışlarını belirlemede kritik öneme sahiptir (Tüzün, 2007). Örgüte olan güven çalışanın örgütün güvenilirliği hakkındaki algısıdır. Genel anlamda örgüt içindeki insanların fikir birliği içinde olmaları, birbirlerine inanmaları anlamına gelmektedir (Kurum, 2013, s. 40).

Örgütsel güven kavramı ile ilgili olarak yazında yer alan birçok sınıflandırma bulunmaktadır. Bunlardan en önemli olanları, Lewicki ve Bunker'in kuramsal modelinde özetlenen şekli ile hesaplanmış güven, bilgi temelli güven ve özdeşleşme temelli güvendir. Hesaplanmış güven tarafların (işçi-işveren) iş ilişkisine başladığı ilk aşamada ortaya çıkmaktadır. Bu güven türünde taraflar güvenme ile ilgili fayda ve maliyet hesabını mantık çerçevesinde yaparlar. Bu hesap sonucunda ortaya çıkan güven, ilişkinin yaratılması ve sürdürülmesi durumunun ilişkiyi kesmeye oranla daha ekonomik olduğunun göstergesidir. Bilgi temelli güven tarafların birbiri hakkında bilgi sahibi oldukları, dolayısıyla önceden ilişki içinde bulundukları durumlarda ortaya çıkmaktadır. Özdeşleşme temelli güven ortamında ise taraflar birbirlerini uzun süredir tanımaktadırlar ve güvenilir bir ilişki geliştirmişlerdir (Bhati ve Zoysa, 2013, s. 37-38). 
Güven, örgüt içi işbirliğini ve uzun süreli istikrarı sağlama, çalışan mutluluğu ve buna bağlı olarak yüksek çalş̧an performansı sağlama konusunda önemli bir unsurdur (Mayer vd., 1995, s. 713). Yüksek örgütsel güvenin olduğu örgütlerde örgüt yapısındaki merkezileşme azalmakta, tersine güven eksikliği durumunda ise merkezileşmeyi artırmakta ve kat1 bir denetim fonksiyonunun işletilmesini gerektirebilmektedir (Sargut, 1994, s. 101-102). Örgütsel güvenin bir örgütteki temel işlevleri, örgüt üyeleri arasındaki işbirliğini artırmak, işlem maliyetlerini azaltmak, örgüt içi kurallara uymayı kolaylaştırmak ve çatışmaları azaltmak olarak sıralanabilir (Kramer, 1999, s. 582).

\section{Örgütsel Bağl1lık}

Örgütsel bağllık çalışanların örgütün hedeflerini benimseyerek örgütün bir parçası olmaları ile ilgili çabalar1 ve örgütü büyük bir aile gibi algilayıp bunun bir üyesi gibi hissetmeleri anlamına gelmektedir. Örgütsel bağlllığ1 yüksek çalışanlar örgütün hedef ve değerlerine inanırlar ve örgüt tarafindan iletilen talimat ve beklentileri karşılamak için gönüllü olarak çaba sarf ederler. Guest’a (1995) göre örgütsel bağlllık İnsan Kaynakları Yönetimi'nin en temel hedeflerinden biridir ve İKY'yi geleneksel personel yönetiminden ayıran bir özelliktir (Al-Esmael, 2007).

Meyer ve Allen (1990) mevcut tek boyutlu örgütsel bağlllık kavramsallaştırmalarının benzerlikleri ve farklılıkları üzerine yaptıkları inceleme sonucunda üç bileşenli örgütsel bağlllık modelini geliştirmişlerdir. Örgüte olan duygusal bağlllık, algilanan maliyet ve devam zorunluluğu şeklinde üç boyutlu bir yaklaşım öne sürmüşlerdir. Meyer ve Allen'e göre örgütsel bağlllı̆ın bu üç konudan bir ve daha fazlasını içerebileceğini savunarak kendi modellerine bunların üçünü de dâhil etmişlerdir. Bu konular etrafinda şekillenen bağlılık türleri arasında ayrım yapabilmek için onları duygusal bağlılık, devam bağlllı̆̆1 ve normatif bağlılık olarak adlandırmışlardır. Bir çalışanın örgüte olan bağllığı farklı derecelerde duygusal, devam ya da normatif bağlılığını içermektedir (Meyer ve Allen, 1990). Duygusal bağglılık kavramı çalışanın içinde bulunduğu örgüte karşı yakınlık hissetmesi ve bu duyguyu sahiplenerek örgütle bir büyün oluşturması olarak açıklanmaktadır. Yüksek duygusal bağlllı̆̆a sahip çalışanlar örgütün değer ve hedeflerini benimseyerek kendi amaç ve hedefleriymiş gibi hareket ederler. Çalışanlar kendilerinden beklenenden daha yüksek bir performans göstererek örgütün bir parçası olarak görülmek isterler (Gürbüz, 2006, s. 59). Devam bağlllı̆̆ı, çalışanın deneyimi, bilgi birikimi ve yatırımları sonucunda oluşmaktadır. Devam bağlılığ1 çalışanın örgütte kalıp kalmamaya karar vermesi sürecinde söz konusu olmaktadır. Örgütte belirli bir süre geçirmiş olan çalışan emek harcayarak bazı kazanımlar elde etmiş olabilir ve ayrılması durumunda bunları kaybedeceğini düşünerek ayrılmayı istese dahi çalışmaya devam edebilmektedir. Bu notada örgütten ayrılmanın maliyetine bağlı olarak çalışanın hayatında çeşitli zorluklar yaşanması muhtemel olabilecektir. Bu durumdaki bağlllık örgütte kalma ihtiyacından ileri gelmektedir (Pelit vd., 2007, s. 3). Normatif bağlliğa sahip çalışanlar örgütte kalıyor olmasının gerekli olduğu konusunda bir algiya sahiptirler. Bu tür bağlllığa sahip çalışan örgüte olan bağlllığın yanlış olmadığını ve göreve yönelik olduğu algisını taşır (Polat ve Meyda, 2011, s. 158).

\section{Psikolojik Sözleşme İhlalleri, Örgütsel Güven ve Örgütsel Bağlılık Arasındaki İlişkiler}

Yazında psikolojik sözleşme ihlalleri, örgütsel güven ve örgütsel bağlllık değişkenleri arasındaki ilişkileri ayıı ayrı inceleyen birçok araştırma vardır. Çalışmalarda ilişkilendirilen çeşitli kavramlar yardımıyla psikolojik sözleşme ihlallerinin, örgütsel güvenin ve örgütsel bağlllığın çalışma hayatına etkileri ortaya konulmaya çalışılmıştır.

Robinson ve diğerleri (1994), yeni işe alınan çalısanların işveren ile karşıllklı istihdam yükümlülükleri konusundaki algılarındaki değişimleri incelemek için iki yıllık bir süre zarfinda uzunlamasına bir çalışma yürütmüşlerdir. Robinson ve diğerleri (1994), çalışanların kendileriyle işverenleri arasındaki karşlıklı yükümlülüklere ilişkin algılarının, ilk iki yıllık çalışma döneminde, algılanan çalışan yükümlülüklerinin azalması ve çoğu işveren yükümlülükleri algısının zaman içinde artmasıyla birlikte önemli ölçüde değiştiğini tespit etmişlerdir. Ayrıca psikolojik sözleşme ihlal algısının hem ilişkisel hem de işlemsel sözleşmelerde oluştuğunu ancak ilişkisel psikolojik sözleşmeler üzerinde daha güçlü bir olumsuz etkiye sahip olduğunu ortaya koymuşlardır.

Robinson ve Rousseau (1994) iş ilişkisi içinde gerçekleşen psikolojik sözleşme ihlallerini incelemişler ve bu ihlallerin çalşanların örgütsel güveni, iş tatmini ve iş ilişkisine devamı üzerindeki etkilerini araştırmışlardır. Robinson ve Rousseau'nun (1994) araştırmasında örneklem grubunun \%55'inin işverenlerinin çalışanların psikolojik sözleşmelerini ihlal ettiği ortaya çıkmıştır. Araştırmada ayrıca 
psikolojik sözleşme ihlallerinin örgütsel güvene, iş tatminine ve iş ilişkisine devem etme isteğine olumsuz etkisi olduğu ve çalışan devir oranını artırdığı tespit edilmiştir. Çalışmada örgütsel güven ve örgütsel bağlılık ayrıca bir bağımlı değişken olarak ele alınmıştır. Bu çalışmanın sonuçlarından bu ilişkide örgütsel güvenin aracılık etkisinin de incelenmesinin katkı sağlayabileceği öngörülebilmektedir.

Turnley ve Feldman 2000 y1lında bir önceki çalışmalarında (Turnley ve Feldman, 1999) kullandıkları örneklem kitlesi üzerinde psikolojik sözleşme ihlalinin işten ayrılma niyeti geliştirme, çalışanların görev ihmali ve örgütsel vatandaşlık davranışı üzerindeki etkilerini inceleyerek bunlar üzerindeki iş tatminsizliği ve karşılanmayan çalışan beklentilerinin aracılık rolünü ortaya koymaya çalışmışlardır. Araştırmanın sonuçlarına göre psikolojik sözleşme ihlali ile çalışanların gönüllü olarak ortaya koydukları örgütsel vatandaşlık davranışı arasında negatif, çalışanların işten ayrılma niyeti ile görev ihmali davranışları arasında pozitif bir ilişki olduğunu ortaya koymuşlardır.

Robinson ve Morrison 2000 yilında gerçekleştirdikleri 18 ay süren uzunlamasına araştırmada psikolojik sözleşme ihlali algısının çalışanlarda oluşturabildiği öfke ve ihanet gibi güçlü duygusal tepkiler arasındaki ilişkiyi incelemişlerdir. Sonuç itibariyle araştırmacılar çalışanlardaki bu güçlü duygusal tepkilerin psikolojik sözleşme ihlali ile doğru orantılı olarak ortaya çıktıklarını ifade etmişlerdir.

Kickul ve Zaper (2000) psikolojik sözleşme ihlali ve prosedürel adaletin çalışanların normatif bağlılı̆̆ına olan etkisini ve proaktif kişilik özelliklerinin normatif örgütsel bağlllık ve çalışanların girişimcilik niyeti ilişkisindeki aracılık rolünü incelemişlerdir. Araştırma sonucunda psikolojik sözleşme ihlali ile prosedürel adalet ve normatif örgütsel bağlllik arasında negatif yönlü bir ilişkinin olduğunu ortaya konulmuştur. Ayrıca araştırmacılar proaktif kişilik özelliğinin normatif örgütsel bağlılık ve çalışanların girişimcilik niyeti ilişkisi içinde aracılık rolünün varlığı ortaya koymuşlardır.

Kickul (2001a) bir diğer çalışmasında psikolojik sözleşme ihlali ile çalışan tutumları (örgütü olumsuz etkileyen tutumlar ve duygusal bağll1ık) ve işten ayrılma niyeti arasındaki ilişkiyi incelemiştir. Araştırmanın sonuçlarına göre ortaya çıkan psikolojik sözleşme ihlali faktörlerinden özerklik ve gelişmenin, ödüller ve firsatlar ile iş güvencesi ve görev sorumluluğun araştırmanın bağımlı değişkenleri ile anlamlı negatif bir ilişki içinde olduğu tespit edilmiştir. Özerklik ve gelişme ile ödüller ve firsatlar faktörleri duygusal bağlllık ile negatif yönlü ve işten ayrılma niyeti ile pozitif yönlü bir ilişkiye sahiptir. Araştırmanın sonuçları itibariyle Kickul, yerine getirilmemiş psikolojik sözleşme vaatlerinin (psikolojik sözleşme ihlalinin) çalışan tutum ve davranışları üzerinden derin etkileri olduğunu ifade etmiştir. Araştırmacı ayrıca bahsi geçen psikolojik sözleşme ihlallerinin çalışanlarda öfke, hüsran, düşmanlık ve hayal kırıklı̆̆1 gibi olumsuz duyguların oluşmasına etken olabildiğini belirtmiştir. Bu çalışmada psikolojik sözleşme ihlallerinin örgütsel bağlılık üzerindeki olumsuz etkileri incelenirken ortaya koyulan olumsuz çalışan davranışlarının örgütsel güveni de olumsuz etkileyeceği öngörülebilmektedir. Bu anlamda bu çalışma bu ilişki içerisinde örgütsel güvenin aracılık rolünün de incelenmesine dayanak olabilecek çalışmalardandır.

Kickul ve Lester 2001 y1lında gerçekleştirdikleri araştırmada psikolojik sözleşme ihlali ile olumsuz çalışan tutum ve tepkileri, iş tatmini ve örgütsel vatandaşlık davranışı (çalışanlar arası yardımlaşma, bireysel inisiyatif alma, kişisel gayret ve sadakatin güçlenmesi) arasındaki ilişkide eşitlik duyarlılı̆̆ının aracılık rolünü incelemişlerdir. Araştırmacılar özellikle psikolojik sözleşme ihlallerinin içsel ve dişsal faktörlerinin eşitlik duyarlılığ1 ile etkileşimleri sonucu etkilenen çalışan tutum ve davranışlarını incelemişlerdir. Araştırma sonuçlarına göre psikolojik sözleşme ihlali ile iş tatmini ve örgütsel vatandaşlık davranışı arasında eşitlik duyarlılığının aracılık rolünün varlığı tespit edilmiştir.

Cassar 2001 yılında gerçekleştirdiği çalışmada psikolojik sözleşme ihlalleri ve örgütsel güven, örgütsel bağlılık ve iş tatmini arasındaki ilişkiyi incelemiştir. Araştırma sonuçlarına göre özellikle sayg1, takdir ve destek gibi psikolojik sözleşme unsurlarının ihlali ile örgütsel güven, örgütsel bağlllık ve iş tatmini arasında negatif yönlü bir ilişki olduğu ortaya çıkmıştır. Bu çalışmada da psikolojik sözleşme ihlalleri ile örgütsel güven ve örgütsel bağllık arasındaki ilişki ayrı ayrı bağımlı - bağımsız değişken ilişkisi içerisinde incelenmiştir. Çalışmanın sonuçları psikolojik sözleşme ihlalleri ve örgütsel bağlılık arasındaki ilişkide örgütsel güvenin aracılık rolünün incelenmesi konusuna dayanak oluşturabilecek niteliktedir.

Lester ve diğerleri (2002) yürüttükleri araştırmada yöneticiler ve çalışanlar arasındaki uyum ve uyumsuzluk durumlarının çalışanların psikolojik sözleşmeleri üzerindeki etkilerini ve psikolojik sözleşme ihlalleri ile örgütsel bağlılık ve çalışan performansı arasındaki ilişkiyi incelemişlerdir. Araştırmacılar psikolojik sözleşme ihlalleri ile çalışan performansı arasında negatif yönlü bir ilişki olduğunu ortaya koymuşlardır. 
Turnley ve diğerleri 2003 yılında gerçekleştirdikleri araştırmada psikolojik sözleşme koşullarının yerine getirilmesi ile çalışan davranışları (performans, örgüte ve diğer çalışanlara karşı örgütsel vatandaşlık davranışı) arasındaki ilişkiyi incelemişlerdir. Araştırma sonuçları psikolojik sözleşme koşullarının yerine getirilmesi ile çalışan performansı ve örgütsel vatandaşlık davranışı arasında anlamlı pozitif bir ilişki olduğunu ortaya koymuştur.

Değinilen araştırmalardaki ilişkilerden hareketle psikolojik sözleşme ihlallerinin örgütsel güven ve örgütsel bağlılık başta olmak üzere çeşitli değişkenleri etkiledikleri görülmektedir. Çalışmaların sonuçları incelendiğinde ortaya konulan direkt etkilerin örgütsel güvenin aracılık etkisinin araştırılmasına dayanak oluşturduğu söylenebilir.

\section{Yöntem}

\section{Araştırma Modeli}

Modelde görüldüğü üzere sırasıyla psikolojik sözleşme ihlalinin örgütsel güvene, örgütsel güvenin örgütsel bağlllığa, psikolojik sözleşme ihlalinin doğrudan ve örgütsel güven aracilığ1yla örgütsel bağlllığa olan dolaylı etkisinin incelenmesi amacıyla oluşturulan hipotezler aşağıda açıklanmaktadır.

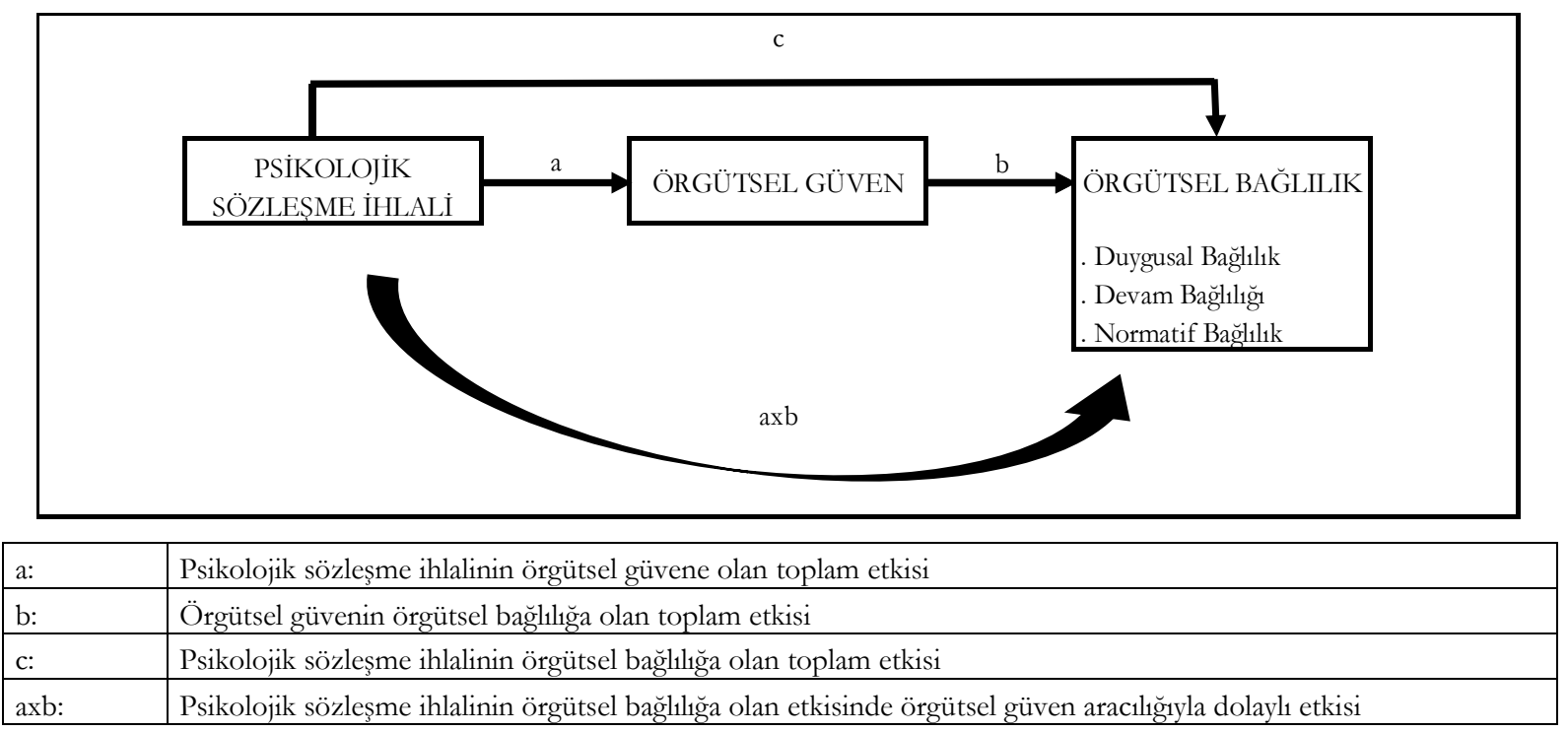

Şekil 1. Arastırma Modeli

\section{Hipotezler}

H1: Psikolojik sözleşme ihlali alg1sının örgütsel güven üzerinde negatif etkisi vardır.

H2: Örgütsel güvenin örgütsel bağlllık üzerinde pozitif etkisi vardır.

H2a: Örgütsel güvenin örgütsel bağlllık alt boyutu olan duygusal bağlllık üzerinde pozitif etkisi vardir.

H2b: Örgütsel güvenin örgütsel bağl1lık alt boyutu olan devam bağl1lı̆̆1 üzerinde pozitif etkisi vardir.

H2c: Örgütsel güvenin örgütsel bağlllık alt boyutu olan normatif bağlllık üzerinde pozitif etkisi vardir.

H3: Psikolojik sözleşme ihlali alg1sının örgütsel bağlllık üzerinde negatif etkisi vardır.

H3a: Psikolojik sözleşme ihlali algısının örgütsel bağlılık alt boyutlarından olan duygusal bağl1lık üzerinde negatif etkisi vardır.

H3b: Psikolojik sözleşme ihlali algısının örgütsel bağlılık alt boyutlarından olan devam bağlllı̆g üzerinde negatif etkisi vardır.

H3c: Psikolojik sözleşme ihlali algısının örgütsel bağlılık alt boyutlarından olan normatif bağlllık üzerinde negatif etkisi vardır. 
H4: Psikolojik sözleşme ihlali alg1sının örgütsel bağllık üzerindeki etkisinde örgütsel güvenin aracılık rolü vardır.

H4a: Psikolojik sözleşme ihlali algısının örgütsel bağlılık alt boyutlarından olan duygusal bağlılık üzerindeki etkisinde örgütsel güvenin aracılık rolü vardır.

H4b: Psikolojik sözleşme ihlali algısının örgütsel bağlılık alt boyutlarından olan devam bağlilı̆̆1 üzerindeki etkisinde örgütsel güvenin aracılık rolü vardır.

H4c: Psikolojik sözleşme ihlali algısının örgütsel bağlılık alt boyutlarından olan normatif bağlılık üzerindeki etkisinde örgütsel güvenin aracılık rolü vardır.

\section{Evren - Örneklem}

Örneklem seçimi: Adana ve Osmaniye'de faaliyet gösteren 3 özel hastane ve 1 özel klinikteki çalışanlara yöneltilen 800 anketten 261'ine dönüş olmuştur. Örneklem kolayda yöntemi ile araştırmanın amacına daha uygun olduğu düşünülerek hizmet sektörü içinden seçilmiştir. Adana ve Osmaniye'de faaliyet gösteren özel hastane ve kliniklerin seçilmesinin nedeni ise bahsi geçen kurumlara ulaşma imkanın diğerlerine nazaran daha elverişli olmasıdır. Araştırma evreni hastanelerde hemşire, hasta bakıcı, ofis personeli gibi doktor olmayan kadrolardan oluşmaktadır ve yaklaşık 3000 kişilik bir büyüklüğe sahiptir. Anket fiziki çıktılar şeklinde hastane yönetimlerine bırakılmış, yaklaşık 45 gün sonunda tekrar toplanarak SPSS programına giriş yapılmıştır. Anket demografik bilgilerle birlikte toplam 4 bölümden oluşmaktadır.

\section{Veri Toplama Araçları}

Psikolojike sözleşme ihlali ölçĕgi; Kickul ve Lester (2001) tarafindan geliştirilmiştir, 19 ifadeden oluşmaktadır. Örgütsel güven ölçeği; Cummings ve Bromiley (1996) tarafindan geliştirilmiştir, 12 ifadeden oluşmaktadır. Örgütsel bağlılık ölçeği; Allen ve Meyer (1990) tarafindan geliştirilmiştir ve 18 ifadeden oluşmaktadir.

Tablo 1. Ölçeklerin Güvenilirlikeleri

\begin{tabular}{lccc}
\hline \multicolumn{1}{c}{ Ölçek } & Cronbach's Alpha & $\begin{array}{c}\text { Standartlaştırllmış İfadelere Dayalı } \\
\text { Cronbach's Alpha }\end{array}$ & İfade Sayısı \\
\hline Psikolojik Sözleşme İhlali &, 938 &, 937 & 19 \\
Örgütsel Güven &, 907 &, 896 & 12 \\
Örgütsel Bağlllık &, 924 &, 921 & 18 \\
ÖB Duygusal Bağlllık &, 862 &, 862 & 6 \\
ÖB Devam Bağlllı̆̆ &, 763 &, 761 & 6 \\
ÖB Duygusal Bağlllık &, 887 &, 882 & 6 \\
\hline
\end{tabular}

Tablo 1'de yer alan verilere göre güvenilirlik analizi sonucunda elde edilen $\alpha$ değerleri kullanılan ölçeklerin oldukça güvenilir ve yüksek derecede güvenilir ölçekler olduğunu ortaya koymaktadır.

Bu çalışmada psikolojik sözleşme ihlali algısı ve örgütsel güven tek boyutlu olarak ele alındığından faktör analizi yapılmamıştır ancak örgütsel bağlılık alt boyutları ile de analize tabi tutulacağından sadece örgütsel bağlılık ölçeği faktör analizine tabi tutulmuştur. Çalışmada kullanılan, Meyer ve Allen (1997) tarafından geliştirilmiş olan üç boyutlu örgütsel bağlllık ölçeğinin yapısal geçerliliği doğrulayıcı faktör analizi ile sınanmıştır. Örgütsel bağlılık ölçeği için gerçekleştirilen doğrulayıcı faktör analizi sonrasında standardize edilmiş faktör yükleri incelenmiştir. Devam bağlılı̆̆1 alt boyutunda yer alan bgll13 ifadesinin ve bgll11 ifadesinin faktör yüklerinin düşük olması nedeniyle analizden çıkarılmıştır. Model uyumunun değerlendirilmesi için uyum indeksleri incelenmiştir. Uyum indeksleri istenilen sonuçları yansıtmadığı için modifikasyon önerileri incelenmiş ve uygulanmıştır. Modifikasyon uygulanmasından sonra uyum indeksleri tekrar hesaplanmış ve Tablo 2'deki sonuçlara ulaşılmıştır. 
Tablo 2. Örgütsel Băghllk Doğrulayıı Faketör Analizi Sonuclar

\begin{tabular}{|c|c|c|c|c|c|}
\hline & Parametreler & Kisaltması & $\begin{array}{l}\text { Mükemmel Uyum } \\
\text { Eşik Değeri }\end{array}$ & Kabul Edilebilir Uyum Aralığ1 & $\begin{array}{l}\text { Örgütsel } \\
\text { Bağll1lık }\end{array}$ \\
\hline \multirow{6}{*}{ 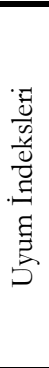 } & Uyum İyiliği İndeksi & GFI & $\geq 0,95$ & $0,90 \leq \mathrm{GFI} \leq 0,95$ & 0,900 \\
\hline & Düzeltilmiş Uyum İndeksi & AGFI & $\geq 0,90$ & $0,85 \leq \mathrm{AGFI} \leq 0,90$ & 0,856 \\
\hline & $\begin{array}{l}\text { Karşılaştırmalı Uyum } \\
\text { İndeksi }\end{array}$ & CFI & $\geq 0,97$ & $0,95 \leq \mathrm{CFI} \leq 0,97$ & 0,954 \\
\hline & $\begin{array}{l}\text { Normalleştirilmiş Uyum } \\
\text { İndeksi }\end{array}$ & NFI & $\geq 0,95$ & $0,90 \leq \mathrm{CFI} \leq 0,95$ & 0,925 \\
\hline & $\begin{array}{l}\text { Yaklassık Hataların } \\
\text { Karekökü }\end{array}$ & RMSEA & $\leq 0,05$ & $0,05 \leq$ RMSEA $\leq 0,10$ & 0,074 \\
\hline & Minimum Tutarsızlık & CMIN/SD & $\leq 2$ & $2 \leq \mathrm{CMIN} / \mathrm{SD} \leq 3$ & 2,424 \\
\hline
\end{tabular}

Kaynak: Schermelleh, Moosbrugger ve Müler (2003); Hu ve Bentler (1999, s.77); Steiger (1990); Marsh ve Hocevar (1985); Ullman, (2001, s. 654).

Tablo 3. Korelasyon Katsaylan

\begin{tabular}{|c|c|c|c|c|c|c|}
\hline & 1 & 2 & 3 & 4 & 5 & 6 \\
\hline Psikolojik Sözleşme İhlali & 1 & & & & & \\
\hline Örgütsel Bağlilık &,$- 692 * *$ & 1 & & & & \\
\hline Örgütsel Güven &,$- 765^{* *}$ &, $802 * *$ & 1 & & & \\
\hline ÖB Duygusal Bağlılık &,$- 722 * *$ & $895^{* *}$ &, $786^{* *}$ & 1 & & \\
\hline ÖB Devam Bağlılığ1 &,$- 445^{* *}$ &, $811 * *$ &, $534 * *$ &, $557 * *$ & 1 & \\
\hline ÖB Normatif Bağlılık &,$- 661 * *$ &, $929 * *$ &, $785^{* *}$ &, $796 * *$ &, $668^{* *}$ & 1 \\
\hline
\end{tabular}

** Korelasyon 0,01 önem düzeyinde anlamlıdır.

Tablodan da anlaşılacağı üzere psikolojik sözleşme ihlali değişkeninin örgütsel güven, örgütsel bağlllık ve örgütsel bağlll1k alt boyut değişkenleri ile negatif anlaml, örgütsel güven değişkeni ile örgütsel bağlll1k ve örgütsel bağllı lı alt boyut değişkenleri arasında pozitif anlamlı farklı düzeylerde ilişki olduğu tespit edilmiştir.

\section{Gerçekleştirilen Analizler}

Bu çalışmada öne sürülen hipotezler regresyon analizi, aracllık etkisi için çoklu regresyon analizi ve Sobel testi ile sınanmıştır. Ayrıca demografik özelliklerin değişkenlere etkisi ise Anova analizi ile incelenmiş, detay farklılıkların ortaya çıarılması için de Tukey testi uygulanmıştır.

\section{Bulgular}

H1: Psikolojik sözleşme ihlali algısının örgütsel güven üzerinde negatif etkisi vardır.

Tablo 4. Psikolojik Sö₹leşme İblali Algissmn Örgütsel Güven Üzerindeki Etkisini Gösteren Regresyon Analiz̨i

\begin{tabular}{llccccc}
\hline & \multicolumn{1}{c}{ Model } & $\boldsymbol{B}$ & Standart Hata & Beta & $\boldsymbol{t}$ & $\boldsymbol{p}$ \\
\hline $1 \quad$ (Sabit) & 4,893 &, 111 & & 44,214 &, 000 \\
& Psikolojik Sözleșme İhlali &,- 695 &, 036 &,- 765 & $-19,054$ &, 000 \\
\hline $\mathrm{R}=0,765 ; \mathrm{R}^{2}=0,585$ & & & & \\
\hline
\end{tabular}

Yapılan analiz sonucunda $\mathrm{H}_{1}$ hipotezi doğrulanmıştır. Yani psikolojik sözleşme ihlali algısının örgütsel güven üzerinde negatif etkisi bulunmaktadır. İşverenin iş ilişkisinin başlangıcında ya da sonrasında çalışan üzerinde oluşturduğu örtük beklentilerin karşılanmaması doğal olarak çalışanın örgüt hakkındaki güvenini de olumsuz etkilemektedir.

H2: Örgütsel güvenin örgütsel bağlllık üzerinde pozitif etkisi vardır

Tablo 5. Örgütsel Güvenin Örgütsel Bağlllk. Üzerindeki Etkisini Gösteren Regresyon Analizi

\begin{tabular}{llccccc}
\hline & \multicolumn{1}{c}{ Model } & $\boldsymbol{B}$ & Standart Hata & Beta & $\boldsymbol{t}$ & $\boldsymbol{p}$ \\
\hline 1 (Sabit) &, 590 &, 122 & & 4,837 &, 038 \\
& Örgütsel Güven &, 867 &, 040 &, 802 & 21,555 &, 000 \\
\hline $\mathrm{R}=0,802 ; \mathrm{R}^{2}=0,643$ & & & & \\
\hline
\end{tabular}


Elde edilen analiz sonuçları $\mathrm{H}_{2}$ hipotezini doğrulamaktadır. Bu durum örgütsel güvenin örgütsel bağlllık üzerinde pozitif etkisi olduğunu ifade etmektedir. Örgütsel güveni yüksek olan çalışanların üyesi olduğu örgütte kalmaya istekli olması beklenen bir davranıştır.

H3: Psikolojik sözleşme ihlali algısının örgütsel bağl1lık üzerinde negatif etkisi vardır.

Tablo 6. Psikolojik Sözleşme İblali Algusınm Örgütsel Bağhluk Üzerindeki Etkisini Gösteren Regresyon Analiži

\begin{tabular}{llccccc}
\hline \multicolumn{1}{c}{ Model } & $\boldsymbol{B}$ & Standart Hata & Beta & $\boldsymbol{t}$ & $\boldsymbol{p}$ \\
\hline 1 (Sabit) & 5,056 &, 134 & & 37,748 & 000 \\
& Psikolojik Sözleşme İhlali &,- 681 &, 044 &,- 692 & $-15,414$ &, 000 \\
\hline $\mathrm{R}=0,692 ; \mathrm{R}^{2}=0,479$ & & & & & \\
\hline
\end{tabular}

Analiz sonuçlarına göre $\mathrm{H}_{3}$ hipotezi doğrulanmıştır. Hipotezde belirtildiği üzere psikolojik sözleşme ihlali algısının örgütsel bağllık üzerinde negatif etkisi olduğu görülmüştür. Psikolojik sözleşme ihlalinin örgütsel güvene olan etkisi gibi örgütsel bağlılık üzerinde de negatif etkisinin olması doğaldır. Taahhüt edilen yükümlülüklerin yerine getirilmediği algısı çalışanın bağlılığında azalmaya hatta işten ayrılma niyeti oluşturmasina neden olabilecektir.

H4: Psikolojik sözleşme ihlali algısının örgütsel bağlllık üzerindeki etkisinde örgütsel güvenin aracılık rolü vardir.

Tablo 7. Psikolojik Sözleşme İblali Algısı ve Örgütsel Bağllık İlişkisinde Örgütsel Güvenin Aracılı. Etkisini Gösteren Hiyerarsike Regresyon Analizi

\begin{tabular}{|c|c|c|c|c|c|c|}
\hline $\mathbf{R}$ & $\mathbf{R}^{2}$ & $\mathrm{OKH}$ & $\mathbf{F}$ & Sd1 & $\mathrm{Sd} 2$ & $\mathrm{p}$ \\
\hline, 8112 & ,6581 & ,3249 & 247,3498 & 2,000 & 257,000 &, 0000 \\
\hline \multicolumn{7}{|c|}{ Direk Etki (c') } \\
\hline Etki & Sh & $\mathrm{t}$ & $\mathrm{p}$ & & & \\
\hline,- 1878 & 0556 & $-3,3744$ & ,0009 & & & \\
\hline
\end{tabular}

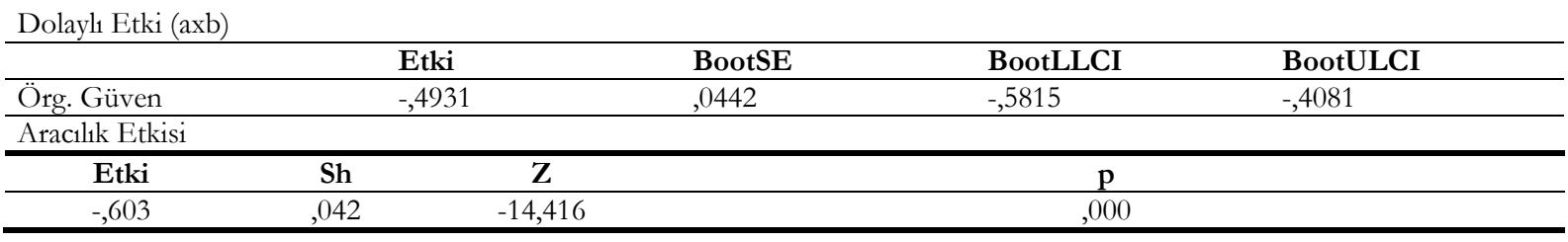

Psikolojik sözleşme ihlali alg1sının ve örgütsel güvenin örgütsel bağlllık üzerindeki etkisinin ortaya konması amaciyla bu iki değişkenin birlikte dahil olduğu regresyon analizinde, ilişkinin anlamlı olduğu görülmektedir (R: 0,8112; R²: 0,6581). Ayrıca bu iki değişkenin örgütsel bağlllı̆̆1 etkileyen birer unsur oldukları da modele beraber dahil edildikleri regresyon analizinde tespit edilmiştir (F: 247,3498; p: 0,000).

Yapılan analizler sonucunda elde edilen verilere göre, psikolojik sözleşme ihlali alg1sı ile örgütsel güven arasında negatif yönlü anlamlı ve örgütsel güven ile örgütsel bağlllık arasında pozitif yönlü anlamlı ilişkiler olduğu görülmüştür. Bu ilişkilerin varlığ1 psikolojik sözleşme ihlalinin örgütsel bağl1lık üzerindeki etkisinde örgütsel güvenin aracılık rolünü test etmeye uygun koşullar sağlamaktadır. Psikolojik sözleşme ihlal alg1sı ve örgütsel güven bağımsız değişkenleri ile örgütsel bağlılık bağımlı değişkeni üzerinde yapılan regresyon analizinde psikolojik sözleşme ihlal alg1sının örgütsel bağlılık üzerindeki doğrudan etkisinin devam ettiği tespit edilmiştir (c'). Ayrıca psikolojik sözleşme ihlal algısının örgütsel güven üzerinde ve aynı zamanda örgütsel güvenin de örgütsel bağlllık üzerindeki anlamlı etkilerinin varlı̆̆1, örgütsel güvenin, psikolojik sözleşme ihlali algısının örgütsel bağl1lık üzerindeki etkisine dolaylı olarak etki ettiğini ortaya koymaktadır. Bu da psikolojik sözleşme ihlali algısının örgütsel bağlılık üzerindeki kısmi bir aracılık etkisini tanımlamaktadır (axb).

Gözlemlenen bu etkinin Sobel arac1lik testi sonucu da (Z: -14,416; p<0,05) ortaya ç1kan etkinin istatistiksel olarak anlamlı olduğunu ortaya koymuştur. Elde edilen bu sonuçlara göre $\mathrm{H}_{4}$ hipotezi kabul edilmiştir. Bu sonuç psikolojik sözleşme ihlali algısının örgütsel bağlılık üzerindeki etkisinde örgütsel güvenin aracılık rolü bulunduğunu ortaya koymaktadır. 


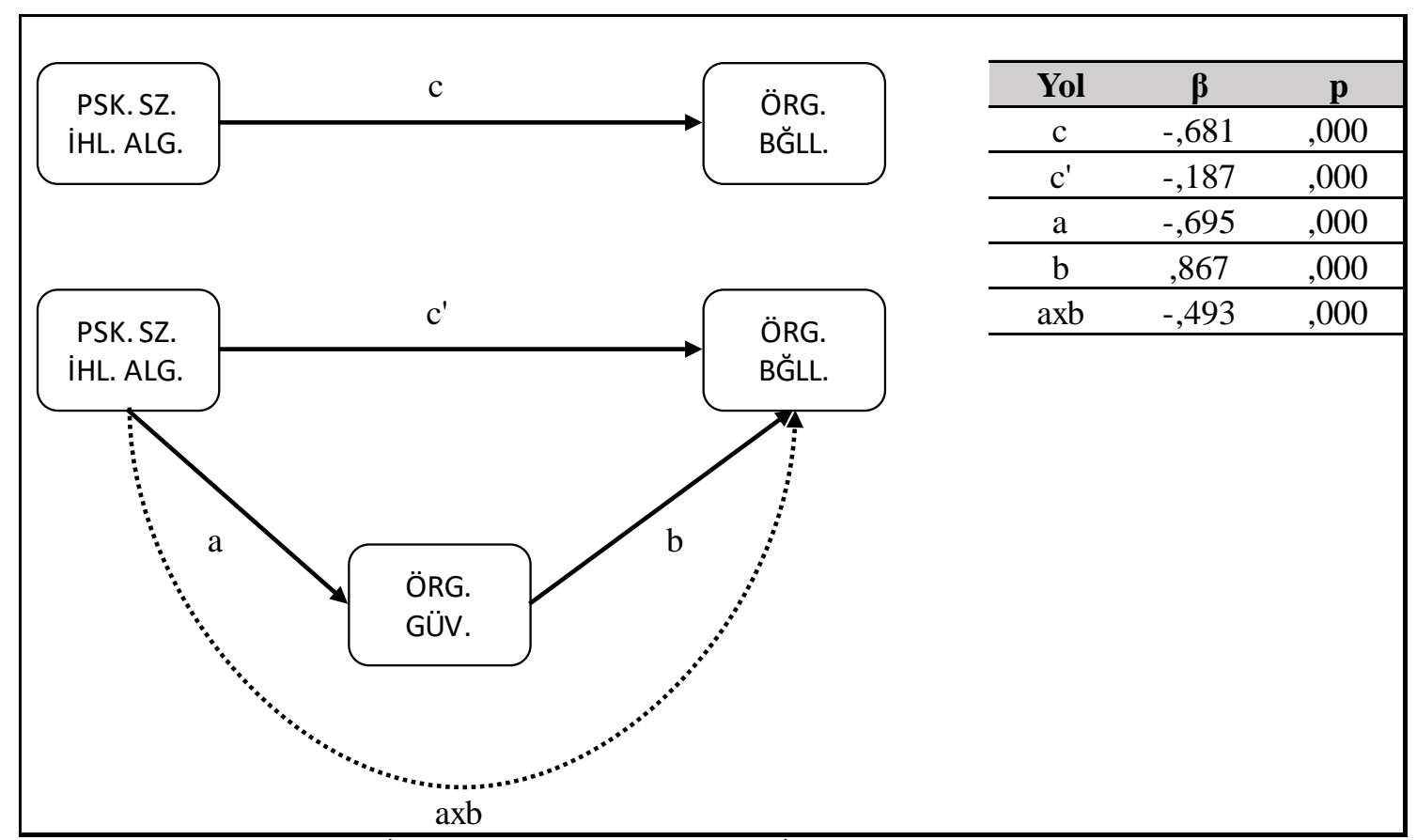

Şekil 2. Psikolojik Sözleşme İhlal Algısı ve Örgütsel Bağhlık İlişkisinde Örgütsel Güvenin Aracılı Etkeisi Şeması

$\mathbf{H}_{2 \mathrm{a}}$ : Örgütsel güvenin örgütsel bağl1lık alt boyutu olan duygusal bağl1lık üzerinde pozitif etkisi vardır.

Çalışmamızda örgütsel güvenin örgütsel bağlllık ölçeğinin alt boyutlarından olan duygusal bağlılık üzerindeki etkisini gösteren doğrusal regresyon analizi sonuçları Tablo 8'de sunulmuştur. Analiz sonuçlarına göre örgütsel bağl1lık ile duygusal bağlllık arasında anlamlı bir ilişki olduğu görülmüştür (R: 0,786; $\mathrm{R}_{2}$ : 0,618). Yapılan ANOVA testi sonuçları örgütsel güvenin duygusal bağlılı̆̆1 etkileyen anlamlı bir değişken olduğunu ortaya koymaktadır (F: 214,934; p:0,000). Regresyon denklemine esas bağımsız değişkenin katsayısının ( $\beta$ : 1,014) anlamlılık testi de örgütsel güvenin duygusal bağlllık üzerinde anlamlı bir etkiye sahip olduğunu ortaya koymaktadır $(\mathrm{p}<0,05)$. Analiz sonuçları $\mathrm{H}_{2 \mathrm{a}}$ hipotezini doğrulamaktadır.

Tablo 8. Örgütsel Güvenin Örgütsel Băghllk Alt Boyutu Olan Duygusal Bağhlık Üzerindeki Etkisini Gösteren Regresyon Analizi

\begin{tabular}{|c|c|c|c|c|c|}
\hline Model & $\boldsymbol{B}$ & Standart Hata & Beta & $t$ & $p$ \\
\hline 1 (Sabit) & , 196 & ,151 & & 1,299 & ,195 \\
\hline Örgütsel Güven & 1,014 &, 050 &, 786 & 20,424 & 000 \\
\hline
\end{tabular}

$\mathbf{H}_{2 \mathrm{~b}}$ : Örgütsel güvenin örgütsel bağlılık alt boyutu olan devam bağlllı̆̆ı üzerinde pozitif etkisi vardır.

Örgütsel güvenin örgütsel bağlllık alt boyutlarından olan devam bağlilı̆̆ına olan etkisini incelemek amacıyla oluşturulan regresyon analizi sonuçları Tablo 9'da sunulmuştur. Analiz sonuçlarına göre örgütsel güven ile devam bağlılı̆̆1 arasında anlamlı bir ilişki olduğu görülmüştür (R: 0,534; $\mathrm{R}_{2}$ : 0,285). Analizde yer alan ANOVA testi sonuçları örgütsel güvenin devam bağlllı̆̆ını etkileyen anlamlı bir değişken olduğunu göstermiştir (F: 102,736; p:0,000). Analizdeki bağımsız değişken katsayısının ( $\beta$ : 0,719) anlamlılık testi ise örgütsel güvenin devam bağlllı̆̆ üzerinde anlamlı bir etkiye sahip olduğunu göstermiştir $(\mathrm{p}<0,05)$. Analiz sonuçları $\mathrm{H}_{2 b}$ hipotezini doğrulamaktadır. Analiz sonuçlarına göre örgütsel güven düzeyi çalışanların işe devamlılığını doğrudan etkilemektedir. 
Tablo 9. Örgütsel Güvenin Örgütsel Bağhllhk Alt Boyutu Olan Devam Bağhlĭ̆ğ Üzerindeki Etkisini Gösteren Regresyon Analizi

\begin{tabular}{llccccc}
\hline & \multicolumn{1}{c}{ Model } & $\boldsymbol{B}$ & Standart Hata & Beta & $\boldsymbol{t}$ & $\boldsymbol{p}$ \\
\hline $1 \quad$ (Sabit) & 1,142 &, 215 & & 5,308 &, 000 \\
& Örgütsel Güven &, 719 &, 071 &, 534 & 10,136 &, 000 \\
\hline $\mathrm{R}=0,534 ; \mathrm{R}^{2}=0,285$ & & & & \\
\hline
\end{tabular}

$\mathbf{H}_{2 \mathrm{c}}$ : Örgütsel güvenin örgütsel bağlllık alt boyutu olan normatif bağlllık üzerinde pozitif etkisi vardır.

Örgütsel bağlılığın bir diğer alt boyutu olan normatif bağlılık üzerinde örgütsel güvenin etkisini incelemek amacıyla gerçekleştirilen regresyon analizi sonuçları Tablo 10'da verilmiştir. Yapılan regresyon analizi sonucunda örgütsel güven ile örgütsel bağlllık alt boyutlarından olan normatif bağllik arasında anlamlı bir ilişki olduğu gözlenmiştir (R: 0,785; R²: 0,617). Analiz içeriğindeki ANOVA testi sonuçları da örgütsel güvenin normatif bağlllı̆̆1 etkileyen anlamlı bir değişken olduğunu göstermiştir (F: 415,300; p:0,000). Ayrıca bağımsız değişken katsayısına ( $\beta$ : 1,05) ilişkin yapılan anlamlılık testi de örgütsel güvenin normatif bağlllık üzerinde istatistiksel olarak anlamlı bir etkiye sahip olduğunu ortaya koymuştur $(p<0,05)$. Analiz sonuçları $\mathrm{H}_{2 c}$ hipotezini doğrulamaktadır. Yani çalışanlanın doğru bir davranış olduklanını düşündükleri için örgüte bağlı olmaları gerektiği konusundaki düşünceleri örgütsel güven düzeyleri ile yakından ilişkilidir.

Tablo 10. Örgütsel Güvenin Örgütsel Băghlık. Alt Boyutu Olan Normatif Bağgllk Üzerindeki Etkisini Gösteren Regresyon Analizi

\begin{tabular}{llccccc}
\hline & \multicolumn{1}{c}{ Model } & $\boldsymbol{B}$ & Standart Hata & Beta & $\boldsymbol{t}$ & $\boldsymbol{p}$ \\
\hline 1 (Sabit) &,- 133 &, 156 & &,- 854 &, 394 \\
& Örgütsel Güven & 1,05 &, 052 &, 785 & 20,379 &, 000 \\
\hline $\mathrm{R}=0,785 ; \mathrm{R}^{2}=0,617$ & & & & \\
\hline
\end{tabular}

$\mathbf{H}_{3 \mathbf{a}}$ : Psikolojik sözleşme ihlali algısının örgütsel bağlılık alt boyutlarından olan duygusal bağl1lı üzerinde negatif etkisi vardir.

Psikolojik sözleşme ihlal algısının örgütsel bağl1lı alt boyutlarından olan duygusal bağlılık üzerindeki etkilerini incelemek amacıyla doğrusal regresyon analizi yapılmıştır. Tablo 11'de gösterilen analiz sonuçlarına göre psikolojik sözleşme ihlali algısı ile duygusal bağlılık arasında anlamlı bir ilişki olduğu ortaya çıkmıştır (R: 0,722; R²: 0,521). Aynı zamanda psikolojik sözleşme ihlali algısı duygusal bağl1lı̆̆ etkileyen anlamlı bir değişkendir (F: 181,402; p<0,05). Analizdeki beta katsayısının ( $\beta$ : $-0,847)$ anlamlılık testi de bağımsız değişken psikolojik sözleşme ihlali algısının anlamlı bir etkiye sahip olduğunu ortaya koymaktadır (p:0,000). Analiz sonuçları $\mathrm{H}_{3 a}$ hipotezini doğrulamıştır. Çalışanların psikolojik sözleşmelerinin ihlal edildiği konusundaki algıları örgüte karşı hissettikleri duygusal bağlllıkları üzerinde olumsuz etkiye sahiptir.

Tablo 11. Psikolojik Sözlessme İblalinin Örgütsel Bağllhk Alt Boyutu Olan Duygusal Bağhllk Üzerindeki Etkisini Gösteren Regresyon Analizi

\begin{tabular}{llccccc}
\hline & Model & $\boldsymbol{B}$ & Standart Hata & Beta & $\boldsymbol{t}$ & $\boldsymbol{p}$ \\
\hline 1 & (Sabit) & 5,566 &, 153 & & 36,318 &, 000 \\
& Psikolojik Sözleşme İhlali &,- 847 &, 051 &, 722 & $-16,767$ &, 000 \\
\hline $\mathrm{R}=0,722 ; \mathrm{R}^{2}=0,521$ & & & \\
\hline
\end{tabular}

$\mathbf{H}_{3 \mathrm{~b}}$ : Psikolojik sözleşme ihlali alg1sının örgütsel bağlılık alt boyutlarından olan devam bağlılı̆̆ı üzerinde negatif etkisi vardir.

Psikolojik sözleşme ihlali algısının bir diğer örgütsel bağlılık alt boyutu olan devam bağlılığı üzerindeki etkileri Tablo 12'de verilmiştir. Analize ait bulgular psikolojik sözleşme ihlali algısının devam bağl1lı̆̆ üzerinde anlamlı ancak zayıf bir etkisinin olduğunu ortaya koymaktadır (R: 0,445; R2: 0,198). Bununla birlikte ANOVA analizi sonuçları psikolojik sözleşme ihlali algısının devam bağlılı̆̆ı alt boyutu için anlamlı bir değişken olduğunu göstermektedir (F: 63,763; p<0,05). Yapılan regresyon analizinde psikolojik sözleşme ihlali algısının devam bağlılığını açıklama oranı \%19,8, regresyon değeri ise $\beta$ : $-0,445$ ve anlamlı olarak ortaya konulmuştur $(\mathrm{p}<0,05)$. Analiz sonuçları $\mathrm{H}_{3 \mathrm{~b}}$ hipotezini doğrular niteliktedir. Yani çalışanların 
devam bağlllığı psikolojik sözleşme ihlallerinden olumsuz etkilenmekte, ihlal durumunda devam bağlllı̆̆1 azalmaktadır.

Tablo 12. Psikolojïk Sözlesme İhlali Algısınn Örgütsel Bağhllke. Alt Boyutlarnndan Olan Devam Bağhlhğ Üzerindeki Etkisini Gösteren Regresyon Analizi

\begin{tabular}{llccccc}
\hline & Model & $\boldsymbol{B}$ & Standart Hata & $\boldsymbol{B e t a}$ & $\boldsymbol{t}$ & $\boldsymbol{p}$ \\
\hline $1 \quad$ (Sabit) & 4,788 &, 207 & & 23,129 &, 000 \\
& Psikolojik Sözleşme İhlali &,- 545 &, 068 &,- 445 & $-7,895$ &, 000 \\
\hline $\mathrm{R}=0,445 ; \mathrm{R}^{2}=0,198$ & & & & \\
\hline
\end{tabular}

$\mathbf{H}_{3 \mathrm{c}}$ : Psikolojik sözleşme ihlali algısının örgütsel bağlılık alt boyutlarından olan normatif bağlllık üzerinde negatif etkisi vardır.

Psikolojik sözleşme ihlali algısının bu çalışma kapsamında örgütsel bağlılık alt boyutlarından olan normatif bağllık üzerindeki etkisi Tablo 13'de gösterilmiştir. Tablodan da anlaşılacağı üzere yapılan regresyon analizi sonucunda psikolojik sözleşme ihlali algısı ile normatif bağlılık arasında anlamlı bir ilişki bulunmaktadır (R: 0,661; R2: 0,437). ANOVA sonuçları da (F: 200,659; p:0,000) psikolojik sözleşme ihlali algısının normatif bağlllı̆ı etkileyen anlamlı bir değişken olduğunu ortaya koymaktadır. Psikolojik sözleşme ihlali algısının normatif bağllılı üzerindeki değişimi açıklama oranı \%43,7 ve regresyon değeri de anlamlı bulunmuştur $(\beta$ : $-0,661 ; \mathrm{p}<0,05)$. Analiz sonuçlarına göre $\mathrm{H}_{3 \mathrm{c}}$ hipotezi doğrulanmışır. Bu sonuçlardan psikolojik sözleşmelerinin ihlal edildiği kanısına sahip çalışanların o örgütte çalışmanın doğru bir karar olduğu, olması gereken bir eylem olduğu konusundaki kanaatlerinin olumsuz etkilendiği söylenebilir.

Tablo 13. Psikolojike Sözlessme İhlali Algısmmn Örgütsel Bağhllk. Alt Boyutlarndan Olan Normatif Bağgllk Üzerindeki Etkisini Gösteren Regresyon Analizi

\begin{tabular}{llccccc}
\hline & Model & $\boldsymbol{B}$ & Standart Hata & Beta & $\boldsymbol{t}$ & $\boldsymbol{p}$ \\
\hline 1 (Sabit) & 5,215 &, 172 & & 30,3 &, 000 \\
& Psikolojik Sözleşme İhlali &,- 804 &, 057 &,- 661 & $-14,165$ &, 000 \\
\hline $\mathrm{R}=0,661 ; \mathrm{R}^{2}=0,437$ & & & & \\
\hline
\end{tabular}

$\mathbf{H}_{4 a}$ : Psikolojik sözleşme ihlali algısının örgütsel bağlılık alt boyutlarından olan duygusal bağlılık üzerindeki etkisinde örgütsel güvenin aracılık rolü vardır.

Çalışmamızda psikolojik sözleşme ihlali algısının doğrulayıcı faktör analizi ile elde edilen örgütsel bağlllık alt boyutlarına olan etkilerinde örgütsel güvenin aracıllk etkileri de incelenmiştir. Bu anlamda örgütsel bağlılığın alt boyutlarından olan duygusal bağlllık üzerinde psikolojik sözleşme ihlal algısının etkisi ve örgütsel güvenin bu etkiye ettiği aracılık rolü Process yazllımı ile incelenmiştir. Elde edilen analiz sonuçları Tablo 14'de sunulmuştur.

Tablo 14. Psikolojike. Sözleșme İhlali Algısı ve Öroütsel Bağhllk. Alt Boyutlarndan Duygusal Bağhllk İlişkisinde Örgütsel Güvenin Arachlk. Etkisini Gösteren Hiyerarşike Regresyon Analizi

\begin{tabular}{|c|c|c|c|c|c|c|}
\hline $\mathbf{R}$ & $\mathbf{R}^{2}$ & OKH & $\mathbf{F}$ & Sd1 & Sd2 & $\mathrm{p}$ \\
\hline ,8082 & ,6532 & ,4695 & 242,0071 & 2,000 & 257,000 &, 0000 \\
\hline \multicolumn{7}{|c|}{ Direk Etki (c') } \\
\hline Etki & Sh & $\mathbf{t}$ & $\mathrm{p}$ & & & \\
\hline,- 3422 & 0669 & $-5,1163$ &, 0000 & & & \\
\hline \multicolumn{7}{|c|}{ Dolaylı Etki (axb) } \\
\hline & & Etki & BootSE & BootLLCI & & BootULCI \\
\hline Örg. Güven & &,- 5053 &, 0536 &,- 6125 & &,- 4043 \\
\hline \multicolumn{7}{|c|}{ Aracıllk Etkisi } \\
\hline Etki & Sh & $\mathrm{Z}$ & & $\mathrm{p}$ & & \\
\hline,- 705 & 050 & $-13,983$ & & 000 & & \\
\hline
\end{tabular}

Tablodan da anlaşılacağı üzere psikolojik sözleşme ihlali algısının ve örgütsel güvenin örgütsel bağglllık alt boyutlarından olan duygusal bağlllı üzerindeki etkisinin ortaya konması amacıyla bu değişkenler birlikte regresyon analizine sokulmuştur. Analiz sonuçları bahsedilen ilişkinin anlamlı olduğunu ortaya koymuştur (R: 0,808; R2: 0,653). Analiz sonucunda bağımsız değişkenlerin duygusal bağglliğ1 etkileyen birer unsur oldukları görülmüştür (F: 242,0071; p:0,000). Değişkenler arasındaki anlamlı ilişkilerin varlı̆̆1 örgütsel güvenin, psikolojik sözleşme ihlali algısının duygusal bağlllık üzerindeki etkisine kısmi olarak 
aracılık etkisi olduğunu ortaya koymaktadır (axb). Gözlemlenen bu etkinin Sobel aracilık testi sonucu da (Z: -13,983; $\mathrm{p}<0,05)$ ortaya çıkan etkinin istatistiksel olarak anlamlı olduğunu ortaya koymuştur. Elde edilen bu sonuçlara göre $\mathrm{H}_{4 a}$ hipotezi kabul edilmiştir. Yani psikolojik sözleşme ihlalinin duygusal bağlilık üzerindeki etkisi örgütsel güven aracıllı̆ıyla da anlamlı sonuç vermekte, çalışanların ihlal alg1sı örgütsel güvenlerini, örgütsel güven seviyeleri de duygusal bağlllıklarını etkilemektedir. Örgütsel güven etkisi kısmi olduğundan aynı zamanda psikolojik sözleşme ihlali algısı duygusal bağlıllğı direkt olarak da etkilemektedir.

$\mathbf{H}_{4 \mathrm{~b}}$ : Psikolojik sözleşme ihlali algısının örgütsel bağlılık alt boyutlarından olan devam bağl1lı̆̆ üzerindeki etkisinde örgütsel güvenin aracılık rolü vardır.

Psikolojik sözleşme ihlali algisının bir diğer örgütsel bağlılık alt boyutu olan devam bağl1lı̆̆ı üzerindeki etkisinde örgütsel güvenin aracılık rolü Tablo 15'de incelenmiştir.

Tablo 15. Psikolojik Sözleşme İhlali Algisı ve Örgütsel Bağhllke Alt Boyutlarndan Devam Bă̆hliğı İlişkisinde Örgütsel Güvenin Araculı Etkisini Gösteren Hiyerarsike Regresyon Analizi

\begin{tabular}{|c|c|c|c|c|c|c|}
\hline $\mathbf{R}$ & $\mathbf{R}^{2}$ & OKH & $\mathbf{F}$ & Sd1 & $\mathrm{Sd} 2$ & $\mathrm{p}$ \\
\hline ,5368 & 2881 & 1,0494 & 52,0065 & 2,000 & 257,000 & 0000 \\
\hline \multicolumn{7}{|c|}{ Direk Etki (c') } \\
\hline Etki & Sh & $\mathbf{t}$ & p & & & \\
\hline,- 1095 & 1000 & $-1,0947$ & 2747 & & & \\
\hline \multicolumn{7}{|c|}{ Dolaylı Etki (axb) } \\
\hline & & Etki & BootSE & BootLLCI & & BootULCI \\
\hline Örg. Güven & &,- 4357 &, 0783 &,- 5859 & &,- 2759 \\
\hline \multicolumn{7}{|c|}{ Aracilik Etkisi } \\
\hline Etki & Sh & $\mathbf{Z}$ & & $\mathrm{p}$ & & \\
\hline,- 500 &, 056 & $-8,968$ & &, 000 & & \\
\hline
\end{tabular}

Yapılan çoklu regresyon analizinde değişkenler arası ilişki anlamlı çıkmıştır (R: 0,536; R2: 0,288). Psikolojik sözleşme ihlali algısının ve örgütsel güvenin, devam bağlilığının anlamlı birer yordayıcısı oldukları, daha önce tek başlarına girdikleri regresyon analizlerinde olduğu gibi beraber girdikleri çoklu regresyon analizinde de ortaya çıkmıştır (F: 52,0065; p:0,000). Psikolojik sözleşme ihlali alg1s1, örgütsel güven ile birlikte devam bağlılı̆̆1 bağımlı değişkeni için girdikleri regresyon sonucunda $(\beta:-0,109 ; \mathrm{p}: 0,274)$ tek başına girmiş olduğu regresyon sonucuna göre ( $\beta$ : -0,545; p:0,000) etkisinde bir düşüş olmakla birlikte istatistiksel olarak devam bağlılığı üzerindeki etki anlamlılı̆̆ını da yitirmiştir. Bu da psikolojik sözleşme ihlali algısının devam bağlllı̆̆ üzerindeki direkt etkisini ortaya koymaktadır (c'). Analizin bağımsız değişkenlerinin anlamlılık düzeyleri psikolojik sözleşme ihlali algısının devam bağlllı̆̆1 üzerindeki etkisinde örgütsel güvenin tam aracılık rolü olduğunu ortaya koymaktadır. Sobel testi sonuçları da ortaya çıkan sonuçların istatistiksel olarak anlamlı olduğunu göstermiştir ( $\mathrm{Z}$ : -8,968; $\mathrm{p}<0,05)$. Analiz sonuçlar1 göre $\mathrm{H}_{4 \mathrm{~b}}$ hipotezini doğrulamaktadır yani psikolojik sözleşme ihlali algısının örgütsel bağlılık alt boyutlarından olan devam bağlılığ1 üzerindeki etkisinde örgütsel güvenin tam aracılık rolü bulunmaktadır. Psikolojik sözleşme ihlalinin devam bağlılığ1 üzerindeki etkisi örgütsel güven aracıllğı ile gerçekleştiğinde direkt etkisi ortadan kalmaktadır. Yani bu ilişki içerisinde psikolojik sözleşme ihlali örgütsel güveni etkilemekte, örgütsel güven de devam bağlllı̆̆ını etkilemektedir.

$\mathbf{H}_{4 \mathrm{c}}$ : Psikolojik sözleşme ihlali algısının örgütsel bağlılık alt boyutlarından olan normatif bağlılık üzerindeki etkisinde örgütsel güvenin aracılık rolü vardır.

Aracılık analizlerinde son olarak ele alacağımız bağımlı değişken örgütsel bağlılık alt boyutu olan normatif bağlılık olacaktır. Bu aşamada da Process yazılımına bağımsız değişken olarak psikolojik sözleşme ihlali algısı, bağımlı değişken olarak örgütsel bağlılık alt boyutlarından normatif bağlılık ve aracı değişken olarak da örgütsel güven tanımlanıp analizler gerçekleştirilmiştir. Analiz sonuçları Tablo 16'da sunulmuştur. 


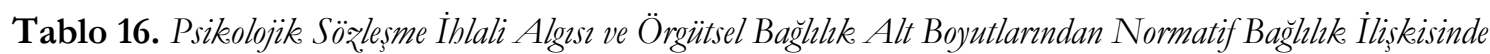
Örgütsel Güvenin Arachlk. Etkisini Gösteren Hiyerarşik Regresyon Analizi

\begin{tabular}{|c|c|c|c|c|c|c|}
\hline $\mathbf{R}$ & $\mathbf{R}^{2}$ & OKH & $\mathbf{F}$ & Sd1 & Sd2 & $\mathrm{p}$ \\
\hline, 7910 & ,6258 & ,5435 & 214,859 & 2,000 & 257,000 &, 0000 \\
\hline \multicolumn{7}{|l|}{ Direk Etki (c') } \\
\hline Etki & Sh & $\mathbf{t}$ & $\mathrm{p}$ & & & \\
\hline,- 1784 & 0720 & $-2,4783$ & 0138 & & & \\
\hline \multicolumn{7}{|c|}{ Dolaylı Etki (axb) } \\
\hline & & Etki & BootSE & BootLLCI & & BootULCI \\
\hline $\begin{array}{l}\text { Örg. Güven } \\
\text { Araclltk Etkisi }\end{array}$ & &,- 6527 & ,0576 &,- 7412 & &,- 5146 \\
\hline Etki & Sh & $\mathrm{Z}$ & & $\mathrm{p}$ & & \\
\hline,- 730 & ,052 & $-13,954$ & & , 000 & & \\
\hline
\end{tabular}

Tabloda görüldüğü üzere psikolojik sözleşme ihlali alg1sı ve örgütsel güvenin normatif bağlllık bağımlı değişkeni ile gerçekleştirilen çoklu regresyon analizi sonucu anlamlı bir ilişki tespit edilmiştir (R: 0,791; R2: 0,625). Psikolojik sözleşme ihlal algısının örgütsel güven ile birlikte normatif bağlllık için girmiş olduğu regresyon sonucunda ( $\beta$ : $-0,178$; p:0,000), normatif bağlllk üzerindeki etkisi tek başına psikolojik sözleşme ihlal algısının girmiş olduğu regresyondaki etkisine ( $\beta$ : -0,804; p:0,000) göre düşüş göstermiş olup etkisinin ve anlamlılığının devam ettiği görülmüştür. Bu durum psikolojik sözleşme ihlali algısının örgütsel güvenin aracılı rolü bulunsa da normatif bağl1lık üzerinde doğrudan etkisinin devam ettiğinin göstergesidir.

Tablo 19'da örgütsel güvenin de normatif bağlllık üzerinde pozitif ve anlamlı bir etkisinin olduğu görülmektedir ( $\beta$ : 0,899; p:0,000). Psikolojik sözleşme ihlali algısının normatif bağlllık üzerindeki doğrudan etkisinin devam etmesi ve ortaya çıkan dolaylı etkinin de anlamlı olmasından kaynaklı olarak, örgütsel güvenin psikolojik sözleşme ihlali algisının normatif bağll1ık üzerindeki etkisinde kısmi aracılık etkisinin olduğu ifade edilebilir. $\mathrm{Bu}$ anlamda $\mathrm{H}_{4 c}$ hipotezi kabul edilmiştir bu durumda psikolojik sözleşme ihlali algisının örgütsel bağlılık alt boyutlarından olan normatif bağl1lık üzerindeki etkisinde örgütsel güvenin aracillk rolü bulunduğu söylenebilir.

\section{Demografik Bilgiler}

Araştırmaya katılan 261 çalşsanın demografik bilgileri incelenmiştir. Buna göre; katılımcıların büyük çoğunluğu kadınlardan $(\% 77,39)$ oluşmaktadır, \%53,64’ü üniversite mezunudur. Katılımcıların \%36,78’i $25-35, \% 34,48$ ' ise 36-45 yaş aralı̆̆ındadırlar ve çalıştıkları iş yerlerindeki kıdemleri ise çoğunlukla 3-5 yıl aralığı için \%36,02 ile 1-2 yıl aralığı için \%34,10 şeklindedir. Katılımcıların büyük çoğunluğu $(\% 77,39)$ yönetici seviyesinde olmayan görevlere sahiptirler.

Tablo 17. Psikolojik Sözlesme İblali Algisı ve Cinsiyet İlișkisi

\begin{tabular}{|c|c|c|c|c|c|c|c|c|}
\hline & Cinsiyet & $\mathrm{N}$ & Ortalama & Standart Sapma & Standart Hata & $\mathrm{t}$ & S.D. & $\mathrm{p}$ \\
\hline \multirow{2}{*}{ Psikolojik Sözleşme İhlali } & Kadın & 202 & 2,9045 & 0,98873 & 0,06957 & \multirow{2}{*}{0,989} & \multirow{2}{*}{259} & \multirow{2}{*}{0,324} \\
\hline & Erkek & 59 & 2,7599 & 0,98605 & 0,12837 & & & \\
\hline
\end{tabular}

Tablondan da anlaşılacağı üzere örneklem grubundaki çalışanların psikolojik sözleşme ihlali alg1ları ile cinsiyet çeşitlilikleri arasında anlamlı bir farklılık bulunmamaktadır ( $\mathrm{p}>0,05)$.

Tablo 18. Psikolojik Sözleşme İblali Algısı ve Issyerindeki Kıdem Anova Analizi

\begin{tabular}{lccccc}
\hline & Kareler Toplamı & S.D. & Ortalama Kare & F & Sig. (p) \\
\hline Gruplar Aras1 & 10,782 & 3 & 3,594 & 3,8 & 0,011 \\
Grup İçi & 243,061 & 257 & 0,946 & & \\
Toplam & 243,843 & 260 & & & \\
\hline
\end{tabular}

Katılımcıların psikolojik sözleşme ihlali algılarının işyerlerindeki kıdemlerine göre farklılık gösterip göstermediği ANOVA ile test edilmiştir. Tablo 18'de sunulan analiz sonuçlarına göre "p" değeri anlamlı olduğundan ( $\mathrm{Sig}=0,011<0,05)$, ankete katılan çalışanların psikolojik sözleşme ihlali algıları, işyerindeki kıdemlerine göre anlamlı bir farklılık göstermektedir. Hangi kıdem aralıklarında anlamlı farklılık olduğunu saptamak amacıyla uygulanan TUKEY testi sonuçlarına göre 1-2 yıllık kıdemi olan çalş̧anlarla 3-5 yıl kıdemi olan çalışanlar arasında anlamlı bir farklılık gözlenmiştir. Bunun nedeni olarak, işe henüz başlamış ve işyerine geçirdikleri süre diğer çalışanlara göre daha kısa olan 1-2 yıllık deneyime sahip olan çalışanların, 
işyerinin şartlarına ilişkin algılarının zaman içinde netleşmesi, işe başlangıçta sahip oldukları yeni bir işe başlamanın verdiği görece yüksek bağlllık ve işyerine duyulan inanç gösterilebilir.

Tablo 19. Psikolojik Sözleşme İblali Algisı ve Öğrenim Durumu ANOV A Analizi

\begin{tabular}{lccccc}
\hline & Kareler Toplami & S.D. & Ortalama Kare & F & Sig. (p) \\
\hline Gruplar Aras1 & 8,273 & 3 & 2,758 & 2,89 & 0,036 \\
Grup İçi & 245,57 & 257 & 0,956 & & \\
Toplam & 253,843 & 260 & & & \\
\hline
\end{tabular}

Katılımcıların psikolojik sözleşme ihlali algılarının eğitim seviyelerine göre farklılık gösterip göstermediği konusuna yönelik yapılan incelemede, yüksek lisans / doktora mezunları ile lise mezunları arasında $(p=0,028)$ ve yine yüksek lisans / doktora mezunları ile üniversite mezunları arasında $(p=0,027)$ arasında anlamlı farklılık bulunmuştur. Özetle yüksek lisans / doktora mezunlarının psikolojik sözleşme ihlali alg1ları üniversite ve lise mezunları ile anlamlı bir şekilde farklıdır. Bu sonuçtan, bu gruptaki çalışanların eğitim seviyelerinin psikolojik sözleşmelerinde yer alan muhtemel taahhütlerin işveren tarafindan daha fazla karşılandı̆̆ı sonucu çıkarılabilir.

Tablo 20. Psikolojik Sözleşme İblali Algısı ve Yaş Durumu ANOV A Analizi

\begin{tabular}{cccccc}
\hline & Kareler Toplamı & S.D. & Ortalama Kare & F & Sig. (p) \\
\hline Gruplar Arası & 8,545 & 3 & 2,848 & 2,98 & 0,032 \\
Grup İçi & 245,298 & 257 & 0,954 & & \\
Toplam & 253,843 & 260 & & & \\
\hline
\end{tabular}

Analiz sonuçlarına göre 45 ve üzeri yaş aralığında bulunan çalışanların 36-45 yaş aralığındaki çalışanlara göre anlamlı bir farklılı̆̆ı söz konusudur. Bu durum 45 yaş ve üzerindeki çalışanların psikolojik sözleşme ihlali algılarının 36-45 yaş aralığındakilere oranla daha düşük olduğu sonucunu ortaya koymaktadır. Bu sonuç 45 yaş üzerindeki çalışanların işten çıkmaları durumunda yeni iş bulma olanaklarının azlığı ile ilgili olabilir.

\section{Tartışma, Sonuç ve Öneriler}

Bu çalışmada psikolojik sözleşme ihlali algısının örgütsel bağlılık ile olan ilişkisi ve bu ilişki sürecinde örgütsel güvenin aracılık rolünün araştırılması amaçlanmıştır. Amaçlanana uygun olarak çalışmada, psikolojik sözleşme ihlali alg1sı ile örgütsel bağll11k arasındaki ilişkide örgütsel güvenin aracılık rolü incelenmiştir. Yazında psikolojik sözleşme ihlali ve örgütsel bağlllık arasındaki ilişki ele alınmış ve bu iki değişken arasındaki etkileşimin varlığ1 vurgulanmıştır (Robinson ve Rousseau, 1994; Kickul ve Zaper, 2000; Kickul, 2001a; Cassar, 2001; Lester ve diğerleri 2002). Ayrıca psikolojik sözleşme ihlali alg1s1 ile örgütsel güven arasındaki ve örgütsel güven ile örgütsel bağlllık arasındaki ilişki de yazında etkileşimi tespit edilmiş konulardandır (Demirel, 2008). Bu bilgiler doğrultusunda ve sosyal değişim kuramı çerçevesinde zincirleme olarak psikolojik sözleşme ihlali algısının çalışanlar üzerinde örgütsel güvenin gerilemesine ve örgütsel güvendeki gerilemenin de örgütsel bağl1lıkta azalmaya neden olacağı düşünülmüştür.

Yazında, psikolojik sözleşme ihlali algısının bağımsız değişken olduğu bazı çalışmalarda (Robinson ve Morrison, 1995) örgütsel güvenin aracilık etkisinin varlığından söz edilmiştir. Ancak çalışmamızda ele alındığı şekliyle örgütsel bağlılığın bağımlı değişken olarak yer aldığı bir çalışma olmaması bu çalışmada elde edilen bulguların önemini artırmaktadır.

Çalışma analizleri iki bölümden oluşmaktadır. İlk bölümde psikolojik sözleşme ihlali algısının örgütsel güvene ve örgütsel bağlllı̆̆a olan etkisinin, diğer taraftan da örgütsel güvenin örgütsel bağllliğa olan etkisinin anlamlılığı test edilmiştir. İkinci bölümde ise psikolojik sözleşme ihlali algısının örgütsel bağlılığa olan etkisinde örgütsel güvenin aracılık rolü incelenmiştir.

$\mathrm{Bu}$ çalışma için geliştirilen hipotezlerin test edilmesi amacıyla hedef kitle olarak Adana ve çevre illerdeki özel hastane ve kliniklerde çalışan insanlar belirlenmiş ve bunların içinde bir örneklem seçilmek suretiyle elde edilen veriler kullanılmıştır.

$\mathrm{Bu}$ çalışmanın sonuçlarına göre çalışanların psikolojik sözleşme ihlali algıları örgüte olan güven seviyelerini olumsuz etkilemektedir $(\beta$ : $-0,695 ; \mathrm{p}<0,05)$. İş ilişkisinin başlangıcı ile birlikte ortaya çıkan, süreç içinde gelişen ve temelinde işveren tarafindan çalışana sunulan açık ya da örtük yükümlülükleri barındıran psikolojik sözleşmeler yazılı sözleşmelerin karşılayamadığı birçok çalışan beklentisini içermektedir. Örgüt tarafından karşılanmayan ya da imkânsızlık nedeniyle karşılanma imkânını yitiren 
yükümlülükler çalışanın içinde bulunduğu örgüte karşı duyduğu güveni zedelemektedir. Bu durumun sonucunda ise çalışan motivasyonunda gerileme, takım çalışmasının sağlıklı yürütülememesi gibi olumsuz çalışan tepkilerine yol açabilmektedir. Bir örgüt içindeki güven ortamının sağlayacağı performans, açık iletişim gibi beklenen örgütsel çıktıların elde edilmesi açısından örgüt yöneticilerinin çalışanların psikolojik sözleşme ihlali algılarının yönetimi konusuna örgüt tarafından sunulan beklentilerin karşılanabilmesi için çaba gösteriyor olmaları örgüt faydasında olabilecektir.

Çalışmanın bir diğer sonucu ise çalışanların psikolojik sözleşme ihlali algıllarının örgütsel bağlllıklarında doğrudan bir düşüşe neden olduğudur $(\beta:-0,681 ; \mathrm{p}<0,05)$. Çalışanların örgütlerine olan bağlllıkları örgütlerin temel hedeflerindendir. Örgütsel bağlılığın yüksek olduğu ortamlarda çalışanların örgüt hedef ve amaçları doğrultusunda daha fazla çaba gösterdikleri görülmektedir. Buna karşılık örgütsel bağllıktaki azalma işten ayrılma ve işten ayrılma niyeti geliştirme, performansta azalma gibi örgüt tarafından beklenmeyen olumsuz çalışan davranışlarını beraberinde getirebilmektedir. Çalışma sonuçlanı, arzu edilen yüksek çalışan bağllığının sağlanmasında çalışanların psikolojik sözleşme ihlali algılarının önemini ortaya koymaktadır.

Çalışmada örgütsel güvenin ise örgütsel bağlllık üzerinde anlamlı pozitif bir etkisi olduğu görülmüştür ( $\beta$ : 0,$867 ; \mathrm{p}<0,05)$. Çalışanların örgütlerine karşı güven düzeyleri ne kadar yüksek olursa örgüte olan bağllıkları da daha fazla olmaktadır. Bu nedenle örgüt içinde geliştirilecek güven ortamı çalışan bağlılığının beraberinde getirdiği olumlu örgütsel çıktılara katkı sağlayabilmektedir.

Psikolojik sözleşme ihlali algısı örgütsel bağll1ık üzerinde örgütsel güven üzerinden dolaylı bir etki yaratmakta ve aynı zamanda örgütsel bağllık üzerinde direkt etki göstermektedir. Yani örgütsel güven, psikolojik sözleşme ihlali algısının örgütsel bağlılığa olan etkisinde kısmi olarak aracılık etmektedir (Etki: $0,603 ; \mathrm{p}<0,05)$.

Çalışmamızın sonuçları psikolojik sözleşme ihlali algısının örgütsel bağlllığı sağlama konusunda büyük önem taşıdığını göstermektedir. Psikolojik sözleşme ihlali alg1sı gerek doğrudan gerekse örgütsel güven aracilığılla dolaylı olarak çalışanların örgütsel bağlllıkları üzerinde etkilidir. Sonuç olarak örgütsel bağllığın sağlanması ve geliştirilmesi konusunda çalışanların psikolojik sözleşme ihlali algılarının payı büyüktür. Ancak yüksek örgütsel güven ortamının sağlanmış olduğu bir işletmede psikolojik sözleşme ihlali algısının oluşması örgütsel güvenin daha az olduğu bir işletmeye göre daha düşük seviyede gerçekleşebilir. Zaman içinde kurulan sağlıklı ilisskilerin sonucu olarak ortaya çıkan yüksek güven ortamı, işverenin imkansızlık ya da diğer nedenlerle daha önceden açık ya da örtük biçimde çalışanlar nezdinde oluşturduğu beklentileri karşılayamaması durumunda bu çalışmanın sonuçlarında belirtildiği derecede örgütsel bağlllı̆̆1 zedelemeyebilir.

Yöneticilerine ve kurumuna güveni yüksek olan bir çalışanın, aniden ortaya çıkan bir ihlal durumunda psikolojik sözleşmesinin ihlal edildiği algısına kapılması beklenmeyebilir. Dolayısıyla bu ihlal durumunda dahi çalışanın örgütsel bağlllığında bir azalma olmayabilir. Nihayetinde yüksek örgütsel güvenin varllğ̆1 psikolojik sözleşme ihlali durumunda örgütsel bağlllıkta bir azalma olmamasına da yol açabilir.

Bu çalışmada incelenen sağlık sektörü çalışanlarının çalışma koşulları da işveren davranışlarını psikolojik sözleşme ihlali olarak algılamasını etkileyebilmektedir. Emek yoğun, uzun çalışma saatleri olan, iş güvencesi devlet sektörüne nazaran daha az olan özel hastane ve kliniklerde çalışan hemşire ve benzeri pozisyonlardaki çalışanların işveren davranışlarını psikolojik sözleşme ihlali olarak algılaması daha muhtemel olabilir. Buna karşıllk devlet sektöründe çalışan benzer pozisyondaki çalışanların kurumun büyüklügü, kural ve uygulamaların daha formel olması ve nihayetinde daha fazla iş güvencesine sahip olması ihlal algılarını da doğrudan etkileyecektir. Ayrıca bu durum ihlal algısının örgütsel güvene ve örgütsel bağlllığa olan etkisinin de farklılaşmasına yol açabilecektir.

Bu çalışma, yazında nispeten yeni bir araştırma konusu olan psikolojik sözleşme kuramının örgütler açısından önemini vurgulamak açısından yazına katkı sağlamayı amaçlamaktadır. Bu anlamda konunun farklı örgütsel çıktılar açısından ve özellikle oldukça sınırlı sayıda gerçekleştirilmiş olan aracıllı etkilerinin incelenmesi açısından izleyen araştırmacılara yol gösterir niteliktedir. Bu alanda gelecekte yapılacak çalışmalar, daha sağlıklı örgütsel çevrenin oluşturulmasına katkı sağlayacaktır.

Çalışmanın sonuçları örgüt yöneticileri açısından da çalışan bağıllığı ve güvenini artırmada bir kaynak olarak değerlendirilebilir. Günümüzün değişen iş yapışş şekilleri daha fazla çalışan katılımı, takım çalışması ve çalışan - örgüt özdeşleşmesini gerektirmektedir. Ayrıca günümüz rekabet koşullarında çalışanların örgüt 
hedeflerini benimsemeleri örgütleri bir adım öne taşıyacaktır. Bu anlamda uygulayıcı konumundaki örgüt yöneticilerinin karar alma ve uygulama aşamasında bu çalışma içeriğinde yer alan bulgulardan faydalanmaları, beklenen örgüt çıktıları elde edebilmeleri açısından yardımcı olacaktır.

\section{Etik Beyan}

“Psikolojik Sö̋leşme İhlali İle Örgütsel Bağhllhe. Arasinda Örgütsel Güvenin Aracullk Rolü” başlıklı çalışmanın yazım sürecinde bilimsel, etik ve alıntı kurallarına uyulmuş; toplanan veriler üzerinde herhangi bir tahrifat yapılmamış ve bu çalışma herhangi başka bir akademik yayın ortamına değerlendirme için gönderilmemiştir. Gerekli olan etik kurul izinleri Çukurova Üniversitesi Sosyal ve Beşeri Bilimler Alanında Bilimsel Araştırma ve Yayın Etiği Kurulu’nun 20.05.2020 tarihli toplantısında (Karar No: 12) alınmıştır.

\section{Kaynakça}

Al-Esmael, B. A. (2007). A comparative investigation of organizational commitment in government, public, and private organizations in Qatar (Doktora Tezi). University of Hull

Allen, N. J. ve Meyer, J. P. (1990). The measurement and antecedents of affective, continuance and nonnative commitment to the organization. Journal of Occupational Psychology, 63(1), 1-18.

Bhati S. ve Zoysa A. D. (2013). Stages of Trust Development in Banking Relationship. Banks and Bank Systems, 8(1), 36-44

Cassar, V. (2001). Violating psychological contract terms amongst Maltese public service employees: occurrence and relationships. Journal of Managerial Psychology, 16(3), 194-208.

Cummings, L. L. ve Bromiley, P. (1996). The organizational trust inventory (OTI). Trust in organizations: Frontiers of Theory and Research, 302(330), 39-52

Çakinberk, A., Derin, N. ve Demirel, E. T. (2011). Shaping of organizational identification by organizational commitment: example of private education institutions in Malatya and Tunceli. Issletme Arastermalar Dergisi, 3(1), $89-121$.

Çetin, M.Ö. (2004). Örgüt kültürü ve örgütsel bağlılı. İstanbul: Nobel Yayınlar1

Dağlı, M. (2016). Psikolojike sö̈leşme ihlalleri, örgütsel vatandaşllk ve örgütsel adalet algısı ilişkisine yönelik bir araștırma (Doktora Tezi). Haliç Üniversitesi, Sosyal Bilimler Enstitüsü.

Demirel, Y. (2008). Örgütsel güvenin örgütsel bağl1lık üzerine etkisi: Tekstil sektörü çalışanlarına yönelik bir araştırma. Yönetim ve Ekonomi: Celal Bayar Üniversitesi İktisadi ve İdari Bilimler Fakültesi Dergisi, 15(2), 179-194.

Erdoğan M. (2015). psikolojik sö̋lesme iblali algısmm örgütsel siniz̨m ve örgütsel bağhllk üzerindeki etkisi: konaklama işletmelerinde bir uygulama (Doktora Tezi). Atatürk Üniversitesi Sosyal Bilimler Enstitüsü, Erzurum.

Gilbert, J. A. ve Tang, T. Li-Ping. (1998). An examination of organizational trust antecedents. Public Personnel Management, 27(3), 321-338.

Guest, D. E. ve Conway, N. (2002). Communicating the psychological contract: An employer perspective. Human Resource Management Journal, 12(2), 22-39.

Johnson, J. L. ve O'Leary-Kelly, A. M. (2003). The effects of psychological contract breach and organizational cynicism: Not all social exchange violations are created equal. Journal of Organizational Behavior: The International Journal of Industrial, Occupational and Organizational Psychology and Behavior, 24(5), 627-647.

Kickul, J. ve Lester, S. (2001). Broken promises: Equity sensitivity as a moderator between psychological contract breach and employee attitudes and behavior. Journal of Business and Psychology, 16(2), 191-217.

Kickul, J., Lester, S. W. ve Finkl, J. (2002). Promise breaking during radical organizational change: do justice interventions make a difference? Journal of Organizational Behavior: The International Journal of Industrial, Occupational and Organizational Psychology and Behavior, 23(4), 469-488.

Kickul, J. ve Zaper, J. A. (2000). Untying the knot: Do personal and organizational determinants influence entrepreneurial intentions? Journal of Small Business \& Entrepreneurship, 15(3), 57-77

Kramer, R. M. (1999). Trust and distrust in organizations: emerging perspectives, enduring questions. Annual Review of Psychology, 50

Kurum, G. (2013). Trakya Üniversitesi’nde görev yapan ögretim elemanlarnnn örgüt sağğğ algzlar ile örgütsel güven düzeyleri arasındaki ilişki (Master's Thesis). Trakya Üniversitesi Sosyal Bilimler Enstitüsü, Edirne.

Mayer R. C., Davis J. H. ve Schoorman F. D. (1995). An integrative model of organizational trust. Academy of Management Review, 20(3), 709-734

Morrison, E. W. ve Robinson, S. L. (1997). When employees feel betrayed: A model of how psychological contract violation develops. Academy of management Review, 22(1), 226-256.

Paine, S. C. (2007). The relationship among interpersonel and organizational trust and organizational commitment (Ph.D. Thesis). Alliant International University.

Pelit, E., Boylu, Y. ve Güçer, E., (2007). Gazi Üniversitesi Ticaret ve Turizm Eğitim Fakültesi akademisyenlerinin örgütsel bağlllık düzeyleri üzerine bir araştırma. Ticaret ve Turiẓm Ë̆itim Fakültesi Dergisi, 1, 86-114

Polat, M., \& MEYDA, C. (2011). Örgüt kültürü bağlamında güç eğilimi ve örgütsel bağlllık ilişkisinde örgütsel Özdeşleşmenin aracılık rolü. Atatürk Üniversitesi İktisadi ve İdari Bilimler Dergisi, 25(1), 153-170.

Robinson, S. L. (1996). Trust and breach of the psychological contract. Administrative Science Quarterly, 41(4), $574-599$. 
Robinson, S. L. ve Morrison, E. W. (1995). Psychological contracts and OCB: The effect of unfulfilled obligations on civic virtue behavior. Journal of Organizational Behavior, 16(3), 289-298.

Robinson S. L. ve Morrison E.. (2000). The development of psychological contract breach and violation: A longitudinal study. Journal of Organizational Behavior, 21, 525-546.

Robinson, S. L. ve Rousseau D. M. (1994). Violating the psychological contract: Not the exception but the norm. Journal of Organizational Behavior, 15(3), 245-259.

Rousseau D. M. (1989). Psychological and implied contracts in organizations. Employee Responsibilities and Rights Journal, 2(2), 128

Sargut, A. S. (1994). Bireycilik ve ortaklaşa davranışçllı ikileminde yönetim ve örgüt kuramları. Ankara Üniversitesi SBF Dergisi, 49(1-2), 321-332

Turnley, W. H., Bolino, M. C., Lester, S. W. ve Bloodgood, J. M. (2003). The impact of psychological contract fulfillment on the performance of in-role and organizational citizenship behaviors. Journal of Management, 29(2), 187-206.

Turnley W. H. ve Feldman D. C. (1999). A discrepancy model of psychological contract violations. Human Resource Management Review, 9(3), 369

Turnley, W. H. ve Feldman, D. C. (2000). Re-examining the effects of psychological contract violations: unmet expectations and job dissatisfaction as mediators. Journal of Organizational Behavior, 21 (1), 25-42.

Tüzün K. İ. (2007). Güven, örgütsel güven ve örgütsel güven modelleri. Karamanoğlu Mehmetbey Üniversitesi Sosyal ve Ekonomike Arastırmalar Dergisi, 2, 93-118.

Vineburgh, J. H. (2010). A study of organizational trust and related variables among faculty members at HBCUs (Doktora Tezi). Graduate College of The University of Iowa

\section{EXTENDED ABSTRACT}

Today, although organizations have similar structural conditions such as technology, volume, capital, they differ in terms of an employee belonging and employee quality. Modern organizations analyze the psychological needs of the employees and take measures to increase corporate belonging instead of the bureaucratic management approach in which the authority and power are dominant. As a result of this comprehension, concepts such as organizational justice, organizational trust, organizational commitment, organizational citizenship behaviour, and psychological contract are frequently explored in the organizational behavior literature. Although employees of an organization have secured themselves in their written agreements, the success of the organization is directly proportional to the degree of psychological bond that the employees have established with the organization. In this sense, the managers and organizations approaching with the awareness that employees are psychological entity are successful by bringing employee loyalty and productivity to the highest level. Organizational practices such as teamwork in modern working life require an environment of high trust and loyalty.

Mutual expectations and commitments form the basis of the employee-employer relationship. Regular execution of this relationship affects employee behaviours, such as employee loyalty and trust in the organization. Expectations and obligations in the employee-employer relationship are carried out within the framework of existing formal laws and regulations. Written contracts, workplace practices, regulations and laws are procedures to regulate working life, as much as possible. Psychological contracts consist of expectationsthatareshapedaccordingtoimplicitorexplicitemployercommitments at the beginning and after the employment relationship. Besides, psychological contracts include all explicit or implicit obligations and responsibilities of the working relationship that today's written agreements and other written processes cannot cover due to physical impossibility. An employee is committed to fulfilling a particular task and showing commitment to the employer. In return, in addition to financial expectations and rewards, they have expectations such as a respected working environment and behavioral structure, civil relations, and gaining internal status. It is not possible to meet all employee expectations, which may change over time, through regulations such as written contracts and laws. The same is valid for employer commitments, as well, over time, the structure of employer commitments may change or lose importance. If these commitments and obligations are not met in time or cannot meet due to impossibility, employees perceive their psychological contracts violated.

In the studies conducted in the organizational behavior literature, the direct effects of psychological contract violations on employee attitudes and behaviours are decrease in efficiency, organizational trust, decrease in organizational commitment, decline in organizational citizenship behaviour, erosion in the perception of organizational justice, developing intention to quit, developing organizational cynicism behaviour, and indirect effects such as failure, inefficiency, and competitive disadvantage in teamwork on organizations were examined. The negative impact of the perception of violation of psychological contract 
on working attitudes and behaviours, in general, affects the success of organizations negatively. Although the effects of the perception of psychological contract violation on organizational commitment, organizational trust, organizational citizenship behavior, and the intention to quit are separately investigated in many studies, the mediating role of organizational trust on the relationship with organizational commitment and psychological contract violation has not been investigated sufficiently. The primary purpose of this study to determine how perceptions of employees violations of psychological contract affect their loyalty to the organization and their trust in the organization and reveal the indirect effect of loss of confidence in the process. In order to test the hypotheses presented in the study, data from a sample of 261 employees working in the health sector in Adana and Osmaniye provinces were used. The research model was tested using a questionnaire prepared by using the scales used in the literature in order to evaluate the participants perception of psychological contract violation, organizational trust and organizational commitment levels. ( $\mathrm{Bu}$ ne la) The results revealed that psychological contract violation had a negative effect on organizational trust and organizational commitment and organizational commitment sub-dimensions, organizational trust had a positive effect on organizational commitment and organizational commitment sub-dimensions. Additionally results indicated the role of organizational trust in the effect of psychological contract violation on organizational commitment had a partial mediating role. In the study, practical results of research results for future research are also discussed. In this context, it will possible to see differences in future researches sample groups, sectors, education levels of employees, income levels, cultural differences, especially in the mediation effects. In addition, the study broadens the theories of psychological contract violation, organizational trust and organizational commitment, and contributes to the literature in this sense. 